\title{
Ortaöğretim Biyoloji, Fizik, Kimya ve Fen Bilimleri Derslerine Ait Öğretim Programlarının Marzano Taksonomisine Göre Analizi
}

\section{Analysis of Secondary School Biology, Physics, Chemistry and Science Courses Curricula according to Marzano Taxonomy}

\author{
Kübra ÇELİKKAYA*, Özlem OKTAY**, Ayşegül YAZAR***, Samih \\ BAYRAKÇEKEN****, Nurtaç CANPOLAT*****
}

\begin{abstract}
Öz: Öğretimin kalitesine, eğitimin en önemli yönlerinden biri olan zengin ve derin bir müfredatla yön verilir. Bu programların yol haritaları olan kazanımların değerlendirilmesinde ise bilişsel sınıflandırmalar, yani taksonomiler kullanılmaktadır. Taksonomiler, öğretim programlarının hedeflerine ulaşmak için oluşturulan kazanımların anlaşılmasına yardımcı olur. Çalışma kapsamında bu taksonomilerden biri olan Marzano taksonomisi ele alınmıştır. Araştırmada; 2018 biyoloji, fizik, kimya ve fen bilimleri dersleri öğretim programları kazanımlarının, Marzano'nun yeni taksonomisine göre incelenmesi hedeflenmiştir. Çalışmada, nitel araştırma desenlerinden biri olan doküman incelemesi kullanılmıştır. Taksonominin bilgi ve bilişsel süreç boyutlarına göre toplam 731 kazanımın betimsel içerik analizi yapılmıştır. Çalışma verileri, frekans ve yüzdelik değerler hesaplanarak tablolaştırılmıştır. Analiz sonuçlarına göre, hiçbir disiplin alanında taksonominin bilgi boyutuna dahil edilen psikomotor alanına ait herhangi bir kazanım bulunmamıştır. Kazanımlar her disiplin alanında, bilgi boyutunda sadece bilgi ve zihinsel işlemler alanlarına dağılmıştır. Bilişsel boyutta ise, alma ve kavrama alanına giren kazanım sayısı oldukça fazladır. Üst düzey becerileri içeren analiz ve bilgiyi kullanma alanlarına giren kazanımlar ise daha az sayıda yer almakta veya hiç bulunmamaktadır. Çalışma sonuçlarının eğitmenler, kitap yazarları ve öğretim programı geliştiricilerine fikir vermesi beklenmektedir. Marzano'nun yeni taksonomisinin birçok farklı disiplinde öğretim programlarını değerlendirmede uygulanabilir olması sağlanmalıdır.
\end{abstract}

Anahtar Kelimeler: Marzano taksonomisi, biyoloji, fizik, kimya, fen bilimleri, öğretim programları.

\begin{abstract}
The quality of teaching is guided by a rich and deep curriculum, one of the most important aspects of education. Cognitive classifications, namely taxonomies, are used to evaluate objectives as the road maps of these programs. Taxonomies help understand the objectives, which are created to achieve the goals of the curricula. As one of these taxonomies, Marzano taxonomy, is discussed in the study. The objectives of 2018 biology, physics, chemistry and science curriculum programs were examined according to the new taxonomy of Marzano. Document analysis, one of the qualitative research methods, was conducted. Descriptive content analysis of 731 objectives was performed with respect to the domains of knowledge and cognitive system of the taxonomy. Data were tabulated by calculating frequency and percentage values. Based on the analysis, there were no any objectives in the procedures of psychomotor in any discipline. Objectives are only distributed in the information and mental procedures in each discipline. In the cognitive process, the number of objectives in the area of retrieval and comprehension is quite high. The objectives that fall into the areas of analysis and knowledge utilization involving high-level skills, are fewer numbers or none at all. The findings of the study are expected to give insight to educators, book writers and curriculum developers. It should be ensured that the new taxonomy of Marzano is applicable in evaluating curriculums in many different disciplines.
\end{abstract}

Keywords: Marzano taxonomy, biology, physics, chemistry, science, curricula.

\footnotetext{
*Bilim Uzman1, Atatürk Üniversitesi, Kazım Karabekir Eğitim Fakültesi, Erzurum-Türkiye, ORCID: 0000-0003-37405119 e-posta: kubraacelikkaya@ hotmail.com

**Dr., Atatürk Üniversitesi, Kazım Karabekir Eğitim Fakültesi, Erzurum-Türkiye, ORCID: 0000-0002-0207-1211, e-posta: oktayozlm@gmail.com

***Yüksek Lisans Öğrencisi, Atatürk Üniversitesi, Kazım Karabekir Eğitim Fakültesi, Erzurum-Türkiye, ORCID: 0000-0001-5316-0954, e-posta: aysglllyzr@gmail.com

****Prof. Dr., Atatürk Üniversitesi, Kazım Karabekir Eğitim Fakültesi, Erzurum-Türkiye, ORCID: 0000-0001-87776714, e-posta: samih@atauni.edu.tr

*****Prof. Dr., Atatürk Üniversitesi, Kazım Karabekir Eğitim Fakültesi, Erzurum-Türkiye, ORCID: 0000-0002-0295-

4823, e-posta: nurtac@atauni.edu.tr
} 


\section{Giriş}

Ülkelerin gelişmesinde eğitimin rolü oldukça büyüktür. İyi bir eğitim sayesinde; düşünen, araştıran, sorgulayan, çözüm üretebilen ve öz güveni yüksek bireyler yetiştirmek mümkündür. Kaliteli bir eğitim, hızla değişen ve gelişen dünyada yeniliklere kolay uyum sağlayabilen nitelikli insan gücüne sahip toplumlar meydana getirir. (Demir, Gacanoğlu ve Nakiboğlu, 2017). Eğitimin en önemli ve baskın bileşenlerinden biri ise öğretim programlarıdır (Deveci, 2018). Öğretim programları, bireyin bir amaca ulaşmasında gerekli olan ve yaşadığ çevrenin beklentilerini karşılayacak kazanımları içeren yol haritalarıdır (Doğan ve Burak, 2018). Bir öğretim programı ister ulusal, ister uluslararası düzeyde olsun dört ana öğeden oluşur: içerik; kazanım, öğrenmeöğretme süreci, ölçme-değerlendirme. İçerik öğesi, program içinde kazanımlara özgü konuların toplamıdır. Kazanım öğesinde, bireyin sahip olması istenen davranışlar yer alır. Öğrenmeöğretme süreci, hedeflere ulaşmada hangi yöntem/metot/strateji/teknik kullanılacağını belirtir. Ölçme-değerlendirme ise kazanımların ne kadarına ulaşıldığının kontrolünü yapar ve verilen eğitime yönelik geri bildirim almayı sağlar (Demirel, 2000). Bu öğelerin hepsinin sistematik, uygulanabilir biçimde, bilimsel verilere ve yaklaşımlara dayalı olması, öğretim programının etkili olup olmayacağına karar vermektedir. Öğretim programının başarılı bir şekilde amacına uygun hizmet edebilmesi için bahsedilen dört öğenin birbiriyle ilişkili olması gerekir.

Kazanımlar öğrenmeye yön vererek öğretimin değerlendirilmesini şekillendiren, öğretimin yapılma süreçlerini içeren ve süreç bitiminde öğrenime dair edinilen çıktıları belirleyen bir kılavuzdur. Öğretim programları hazırlanırken, kazanımların programın konu içeriğiyle uyumlu ve programları değerlendirmeye yönelik olarak hazırlanması gerekir (Anderson ve Krathwohl, 2001; Zorluoğlu, Şahintürk ve Bağrıyanık, 2017). Kazanımlar, öğrencileri sadece ezberlemeye yönlendirmemeli, onları bilgiye ulaşan ve bilgiyi araştıran bireyler olarak yetiştirmelidir (Amer, 2006). Özellikle soyut konular ve anlaşılması zor günlük olaylar barındıran fen programlarında, öğretim hedeflerinin kavramsal anlama ve anladığını anlamlandırmaya yönelik olması beklenmektedir. Kazanımların bilişsel yönden ele alınması bu anlamda önemlidir (Çelikkaya, 2019). Programları oluşturan kazanımların konu ve beceri olarak hangi hedefleri geliştirmeyi beklediğini gösteren bir sınıflamaya, yani taksonomiye ise ayrıca ihtiyaç duyulmaktadır. Kazanımları detaylı olarak sınıflama ve kendi içinde aşamalı olarak gruplandırma, eğitimde belirlenen sürecin sağlıklı bir şekilde ilerleyebilmesi açısından önem arz etmektedir (Ayvacı, Alev ve Yıldız, 2015). Bilişsel, duyuşsal ve psikomotor alanlarla ilgili kazanımlar, her bir alanın içerisinde hiyerarşik olarak sınıflandırılmaktadır. $\mathrm{Bu}$ yapı, kazanımların taksonomisi (sınıflandırılması) şeklinde adlandırılmaktadır (Özdemir, Altıok ve Baki, 2015).

Taksonomi, genel olarak eğitim sürecinde kazandırılmak istenilen davranışların birbirinin ön koşulu olacak şekilde aşamalı olarak bilinenden bilinmeyene, kolaydan zora, yakından uzağa, somuttan soyuta, basitten karmaşığa doğru dizilmesine denir (Sönmez, 2015). Hem eğitimde istendik amaçların planlı ve somut olarak ortaya konulup programların etkin bir şekilde hazırlanması, hem de nitelikli bir eğitim öğretimin gerçekleştirilebilmesi açısından taksonomiler önemli yol göstericilerdir (Demir, 2015). Eğitmenler, taksonomiler sayesinde hedeflenen davranışların taksonomilerin hangi basamağında olduğunu bilir, böylelikle derslerini daha somut ve gözlenebilir şekilde tasarlar. Derslerde sınav sorusu hazırlarken ve öğrencileri değerlendirmede taksomomiler oldukça kullanışlıdır.

Programların hazırlanması ve değerlendirilmesinde kullanılan taksonomilerden biri de Marzano'nun yeni taksonomisidir. Bu taksonominin kullanımı, değişik bilgi türlerinin programlarda yer almasını ve bu bilgilerin özel şekillerde işlenmesini sağlama hususunda oldukça faydalıdır. Böylece, öğretim programlarının zenginleşmesine katkı sağlar. Bu taksonomide psikomotor işlemler, bilişsel alanda bir bilgi çeşidir. Psikomotor beceriler de zihinde depolanır ve bu işlem seviyesine ulaşmada izlenen yollar, zihinsel işlemlere ulaşmadakilerle benzerdir (Marzano, 2001). Marzano'nun taksonomisi, Bloom taksonomindeki basamaklara benzerlikler gösterse de alt basamaklar açısından birtakım farklılıklar yer almaktadır. Ayrıca Marzano'nun 
taksonomisi, programların değerlendirme süreçlerini tasarlamak için bir çerçeve oluşturmaktadır (Marzano ve Kendall, 2007). Bu özelliklerinden dolayı bu çalışmada; ortaöğretim biyoloji, fizik, kimya ve fen bilimleri derslerine ait öğretim programları kazanımlarının değerlendirilmesinde Marzano'nun yeni taksonomisi kullanılmıştır.

\section{Marzano'nun taksonomisi}

Tanınmış bir eğitimci olan Robert J. Marzano, 2000 yılında eğitim amaçlarının sınıflandırılması için yeni bir taksonomi önermiştir. Bu taksonomi, son derece yaygın olarak kullanılan Bloom taksonomisinin ve ayrıca program standartlarına dayalı öğretimin temellendirilmesindeki yetersizlikleri gidermek için geliştirilmiştir. Marzano'nun düşünme becerileri taksonomisi, öğrencilerin düşünme süreçlerini etkileyen birçok boyutu kapsamakta ve öğrencilerin düşünme becerilerini geliştirme konusunda öğretmenlere destek olacak araştırma esaslı bir teori sunmaktadır. Böylece Marzano'nun taksonomisinin, Bloom taksonomisine göre biraz daha iyi işlev gördüğ̈̈ söylenebilir. Marzano'nun taksonomisinin en son beyin temelli öğrenme alanyazınına dayalı olarak bütünleşik tam bir öğrenme teorisi sunduğu ise ayrıca ifade edilmektedir (Marzano ve Kendall, 2007). Marzano'nun düşünme becerileri taksonomisi, öğrencilerin düşünce sürecini etkileyen temel yönleri kapsar. Marzano taksonomisinin derslerin planlanmasında ve program geliştirme çalışmalarında kullanımının, çeşitli üst düzey bilgi ve becerilerin kazandırılması açısından iyi bir çerçeve sağladığı söylenebilir (Marzano ve Kendall, 2007). Marzano'nun ilk taksonomisi beş boyuttan oluşmaktadır. Bu boyutlar aşağıdaki gibidir:

1- Öğrenme ile ilgili olumlu tutumlar ve algilamalar,

2- Bilginin kazanılması ve bütünleştirilmesi,

3- Bilginin genişletilerek işlenmesi,

4- Bilginin anlamlı olarak kullanılması,

5- Aklın üretken alışkanlıkları (Marzano vd., 1997).

Marzano sonradan bu taksonomiyi geliştirerek yeni bir taksonomi ortaya koymuştur (Marzano, 2001). Marzano yeni taksonomisinde adeta Bloom'un eksikliklerini tamamlayıcı nitelikte öneriler ortaya koymaktadır (Irvine, 2017; Timofte ve Siminiciuc, 2018). Marzano'nun yeni taksonomisi başlıca iki boyut içermektedir. Bu boyutlardan birincisi, "bilginin alanları", ikincisi ise "süreç düzeyleri” olarak isimlendirilmiştir (Marzano ve Kendall, 2007).

Taksonomide bilginin alanları, üç temel alanı kapsamaktadır. Bu alanlar bilgi, zihinsel işlemler ve psikomotor işlemlerdir. Marzano her bir bilgi alanı için alt basamaklar ortaya koyarak oldukça ayrıntılı bir sınıflama yapmıştır. Genel olarak öğretimde belirleyici faktörlerden biri olan bilgi alanına önemli vurgular yapılmaktadır (Viji ve Benedict, 2017). Bu alan son derece önemli olup, ilgilenilen bir konu hakkında yeterli düzeyde bilginin bulunmaması durumunda öğrenme sürecinin arzu edilen kapasiteye ulaşabilmesi noktasında diğer sistemlerin yeterli olamayacağını söyler. Bu açıdan düşünme süreci besleyicisinin bilgi alanı olduğu açıktır. Bu alan kavramları sınıflandırarak, daha az çaba ve daha fazla bilgi kazanmaya izin veren prensipler ve genellemeler gibi organize edicileri içermektedir. Zihinsel işlemler, basitten oldukça karmaşık işlemlere kadar çok fazla değişkenlik gösterebilir (Marzano ve Kendall, 2007). Psikomotor beceriler ise bedensel ya da el becerileri denilen alanı kapsamaktadır.

Marzano, yeni taksonomisindeki süreç düzeylerini üç temel sistem olarak birbirinden ayırmıştır. $\mathrm{Bu}$ sistemler aşağıdaki gibidir (Marzano ve Kendall, 2007):

1-Bireyin kendi sistemi

2-Bilişötesi sistem

3-Bilişsel sistem

- Bilgiyi kullanma

-Analiz

- Kavrama

-Alma 
$\mathrm{Bu}$ boyutta yer alan bilişsel sistem; alma, kavrama, analiz ve bilgiyi kullanma şeklinde dört kategoriden oluşmaktadır. Bilişsel sistem içerisinde yer alan bu dört kategori arasında hiyerarşik bir ilişki bulunmaktadır (Toledo ve Dubas, 2016). Burada alma, uzun süreli hafızada saklanan bilgilerin basitçe geri çağrılması ile ilgilidir. Kavrama, hatırlamaya göre daha yüksek düzey olup, bilgileri uygun kategorilere koymak ve hangi bilgilerin hatırlanmasının önemli olduğunu bilme ile ilgilidir. Analiz, eşleştirme, sınıflama, hata analizi, genelleme ve belirtme gibi bilişsel süreçleri içerir ve yeni durumlarda bu süreçleri kullanan öğrenci, yeni bir bakış açısı geliştirir. Bilgiyi kullanma ise bilişsel sistemin son seviyesidir. Bu seviye karar verme, problem çözme ve deneysel araştırmayı içerir. İnsanlar belirli bir görevi başarmak istediklerinde bu süreçleri kullanırlar. Süreç boyutundaki bir diğer sistem bilişötesi sistemdir. $\mathrm{Bu}$ sistem kendi öğrenmemiz üzerine düşünmemiz ile ilgilenir. Bu düşüncelerimiz, bilişsel alandaki öğrenme yaklaşımımızı düzenler. Yani bu sistem, yeni bilgiyi kavrayabilme ve öğrenebilmenin en iyi stratejilerini bilmemize yardımcı olur. Süreç boyutunda ayrıca bireyin kendi sistemi yer almaktadır. Bireyin kendi sistemi, bir görevi gerçekleştirme motivasyonunu ya da dürtüsünü yönlendiren tutum, inanç ve duyguları içermektedir. Kişi bu sistemi kullanarak bir işi yapmaya ya da yapmamaya karar verir (Viji ve Benedict, 2017). Aşağıda verilen Şekil 1'de Marzano taksonomisinin bir özeti yer almaktadır.

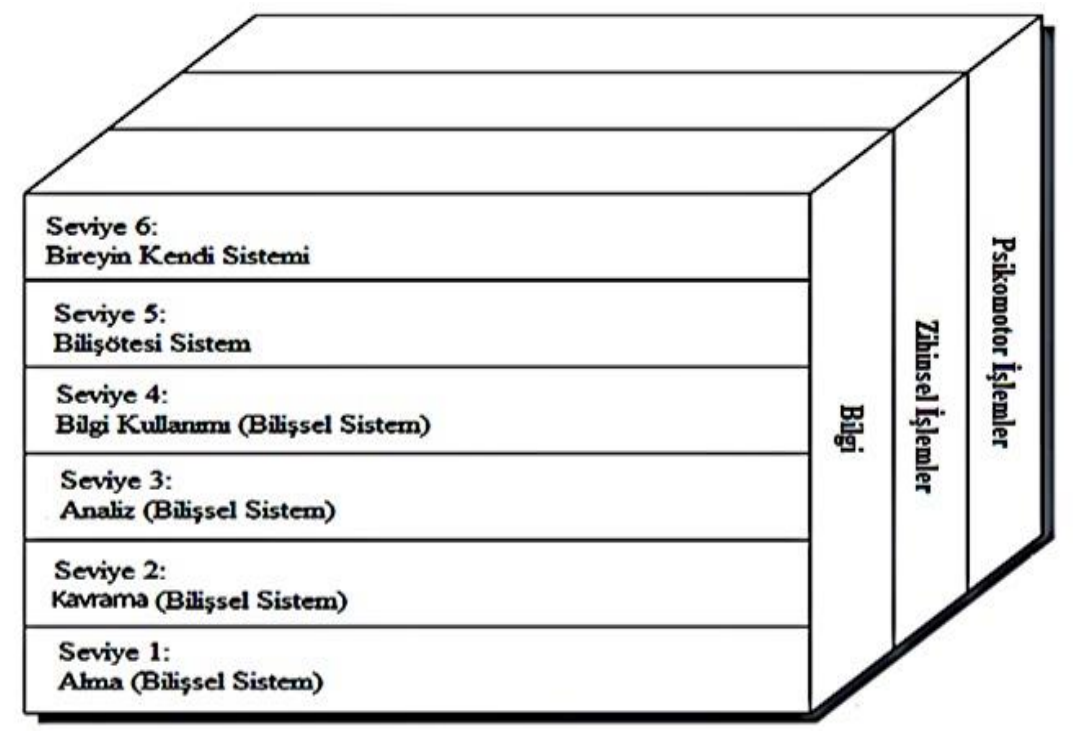

Şekil 1. Marzano taksonomisindeki işleme seviyeleri (Marzano ve Kendall, 2007)

\section{Araştırmanın amacı}

Bu çalışmada ortaöğretim biyoloji, fizik, kimya ve fen bilimleri dersleri öğretim programında yer alan kazanımların, Marzano taksonomisindeki bilgi ve bilişsel süreç boyutlarına göre değerlendirilmesi amaçlanmıştır. Buradan hareketle bu çalışmanın temel problemi, "Biyoloji, Fizik, Kimya ve Fen Bilimleri derslerine ait öğretim programlarındaki kazanımların Marzano 'nun yeni taksonomisi ile uyum düzeyi nedir?" olarak belirlenmiştir. Bu probleme dayalı olarak araştırmanın alt problemleri aşağıdaki gibidir:

1- Ortaöğretim Biyoloji Dersi Öğretim Programı kazanımlarının, Marzano'nun yeni taksonomisinde bilgi ve bilişsel süreç boyutlarındaki dağılımı nasıldır?

2- Ortaöğretim Fizik Dersi Öğretim Programı kazanımlarının, Marzano'nun yeni taksonomisinde bilgi ve bilişsel süreç boyutlarındaki dağılımı nasıldır?

3- Ortaöğretim Kimya Dersi Öğretim Programı kazanımlarının, Marzano'nun yeni taksonomisinde bilgi ve bilişsel süreç boyutlarındaki dağılımı nasıldır?

4- Fen Bilimleri Dersi Öğretim Programı (İlkokul ve Ortaokul 3, 4, 5, 6, 7 ve 8. sinıflar) kazanımlarının Marzano'nun yeni taksonomisinde bilgi ve bilişsel süreç boyutlarındaki dağılımı nasıldır? 


\section{Araştırmanın önemi}

Bir eğitimin nitelikli olabilmesi için, öğretimde hedeflerin gerçekleştirilmesine yardımcı olacak kazanımların etkili bir şekilde sınıflandırılması gerekmektedir. Bu sayede programın, iyi yönleri veya eksiklikleri açık bir şekilde ortaya konur. Öğretim programlarıyla öğrenciye sunulan bilişsel düzey ile ölçme-değerlendirme düzeyinin birbirlerine paralel olup olmadığı, programın hedeflere ulaşıp ulaşmadığı (Yüksel, Ayten ve Hayırsever, 2019) yine kazanımların sınıflandırması neticesinde fikir verir. Taksonomiler ile ortaya konulan farklı seviyelerdeki becerilerin kazandırılması açısından, öğretim programlarının yeterli olup olmadığının bilinmesi ve değerlendirilmesi önemlidir. Bundan dolayı elde edilen bulgular, yapılacak olan program revizyonları açısından bir dönüt niteliği taşıyacaktır. Böylelikle, programların analizini yapacak kişilere çeşitli veriler sağlanması, eğitmenlerin daha verimli ve etkili bir öğretim gerçekleştirmesi, ayrıca öğretim bitiminde eğitmenlerin öğretimi iyi bir biçimde değerlendirmelerine 1şık tutması sağlanabilir. Özelikle yeni uygulamaya konulan programların uygulayıcıları açısından aynı şekilde anlaşılması ve ortak bir dil olarak kabul görmesi gerekir. Bu anlamda da 2018 yılında MEB tarafından güncellenen fen grubu programlarındaki kazanımların incelenmesi, programların değerlendirilebilmesi için bir veri sağlayacaktır. Bilindiği üzere öğrenciler fen grubu derslerini daha karmaşık bulup, derse yönelik olumsuz tutum içinde olabilmektedirler (Koca ve Şen, 2006). Kazanımların belirli bir taksonomik yaklaşıma göre incelenmesi yoluyla fen derslerinin şekillenmesi, öğrencinin fen derslerine olan yaklaşımlarını dolaylı olarak etkileyebilir.

Bloom taksonomisiyle ilgili ulusal alanyazın incelendiğinde, uluslararası alana benzer şekilde oldukça fazla çalışmanın yapıldığı ve alanda kabul gördüğü (Arı, 2013) görülmektedir. Çalışmaların bir kısmı, eğitim öğretim süreci boyunca sorulan soruların Bloom taksonomisine uygunluğunu, bir kısmı da öğretim programlarındaki kazanımların taksonomiye göre incelenmesini içermektedir. (Avşar ve Mete, 2018; Ayvacı ve Şahin, 2009; Büyükalan ve Baysal, 2019; Cangüven, Öz, Binzet ve Avc1, 2017; Eke, 2015; Eroğlu ve Kuzu, 2014; Gökler, Aypay ve Arı, 2012; Karagöl, 2020; Karip, 2019; Tanık ve Saraçoğlu, 2011; Zorluoğlu, Olgun ve Kızılaslan, 2020; Zorluoğlu, Güven ve Korkmaz, 2017). Son y1llarda ise uluslararası çalışmalarda Marzano taksonomisini ele alan çalışmalar artmaktadır (Asmi, Wonorahardjo ve Widarti, 2019; Dubas ve Toledo, 2016; Insani, Pratiwi ve Muhardjito, 2019; Nakyam, Kwangsawad ve Sriampai, 2013; Rasyidi ve Winarso, 2020). Ulusal alanyazında Marzano taksonomisinin kullanıldığ bir tez çalışması (Çelikkaya, 2019) ve bir makale (Karadağ ve Kaya, 2017) bulunmaktadır. Karadağ ve Kaya (2017) tarafından yapılan çalışmada Marzano taksonomisine göre ilkokul programlarındaki kazanımlar ele alınırken, Çelikkaya (2019) tarafından yapılan çalışmada ise 2018 ortaöğretim kimya dersi öğretim programı kazanımları Marzano taksonomisi ele alarak değerlendirmiştir. Geniş bir kapsam oluşturularak ulusal boyutta ortaöğretim biyoloji, fizik, kimya ve fen bilimleri derslerine $(3,4,5,6,7$ ve 8 . sınıflar) ait öğretim programlarında yer alan kazanımların tümünün Marzano'nun taksonomisine göre incelendiği herhangi bir çalışmaya ise rastlanmamıştır. Oysaki farklı taksonomilerin kullanılması ve uygulama alanlarının geliştirilmesi önerilmektedir (Yüksel, 2007). Bu sayede, taksonomilerin güçlü ve zayıf tarafları ortaya çıkar, kullanabilirlikleri irdelenir ve taksonomilere olan farkındalık artar. Bu çalışma ile seçilen öğretim programlarında yer alan kazanımların Marzano taksonomisine uygunluğu belirlenerek, kazanımların boyut karşılaştırmaları ile alanyazındaki boşluğun doldurulacağı ve öğretim programlarının değerlendirilmesine katkı sağlanacağı düşünülmektedir. Böylelikle, mevcut programların analizlerini yapacak kişilere birtakım veriler sağlanması hedeflenmektedir.

\section{Yöntem}

$\mathrm{Bu}$ araştırma için nitel araştırma desenlerinden olan doküman incelemesi kullanılmıştır. Doküman incelemesi, veri toplama yöntemi olarak kullanılmasının yanında, bir analiz biçimi olarak da kullanılabilir (O'leary, 2004). Bu analiz, hedeflenen araştırma amacına göre seçilen olgu ve olaylara yönelik bilgilerin bulunduğu yazılı kaynakların sistemetik bir şekilde değerlendirilmesidir (Bowen, 2009; Yıldırım ve Şimşek, 2016). Araştırmada çalışmanın amacına bağlı olarak, 2017 yılı itibariyle yayınlanan ve 2018 yılında güncellenerek uygulanmaya konulan 
ortaöğretim biyoloji, fizik, kimya ve fen bilimleri derslerine $(3,4,5,6,7$ ve 8 . sinıflar) ait öğretim programları kazanımları incelenmiştir. Öğretim programlarındaki toplam 731 kazanım çalışmaya dahil edilmiştir.

\section{Veri toplama ve süreci}

2018 yılında güncellenerek uygulanmaya konulan ortaöğretim biyoloji, fizik, kimya ve fen bilimleri dersleri $(3,4,5,6,7$ ve 8. sınıflar) öğretim programları kazanımları Marzano'nun yeni taksonomisi kullanılarak incelenmiştir. Veri kaynağı olarak biyoloji, fizik, kimya ve fen bilimleri derslerine ait öğretim programları kullanılmıştır. Bu programlara Mili Eğitim Bakanlığı'nın (MEB) öğretim programlarını izleme ve değerlendirme sistemi (http://mufredat.meb.govtr/Programlar.aspx) üzerinden doğrudan ulaşılmıştır. Öncelikle, araştırmacılar ortak bir fikir birliğine varmak amacıyla bir araya gelmişler, rastgele bir öğretim programı (kimya) ve bir ünite seçerek (9. sınıf kimya bilimi ünitesi) beraberce kodlama yapmışlardır. Sonrasında üç araştırmacı öğretim programları kazanımlarını paylaşarak ayrı ayrı çözümlemiş ve bireysel farklılıklar oluştuğunda bir araya gelerek, ortak bir fikir birliğine ulaşmışlardır. Diğer iki araştırmacı ise her alandan rastgele seçim yaparak, kodlamalar için son kontrolleri yapmışlardır. Kazanımların taksonomideki yeri, bilgi boyutunda üç kategoride (bilgi, zihinsel işlemler, psikomotor işlemler) ve bilişsel boyutta dört kategoride (alma, kavrama, analiz, bilgiyi kullanma) belirlenmiştir. Aşağıda verilen Tablo 1'de Marzano'nun yeni taksonomisine göre bilgi ve bilişsel boyut alanlarına ait kodlanan kazanımlardan bazı örnekler verilmiştir.

Tablo 1

Marzano Taksonomisinin Bilgi ve Bilişsel Boyut Alanları ve Örnek Kazanımlar

\begin{tabular}{|c|c|}
\hline \multicolumn{2}{|r|}{ Bilgi Boyutu } \\
\hline Bilgi & 11.1.8.1. Tork kavramını açıklar. (Fizik) \\
\hline Zihinsel işlemler & $\begin{array}{l}\text { 5.4.2.1. Yaptığ } 1 \text { deneyler sonucunda saf maddelerin erime, donma, } \\
\text { kaynama noktaların } \text { belirler. (Fen Bilimleri) }\end{array}$ \\
\hline $\begin{array}{l}\text { Psikomotor } \\
\text { işlemler }\end{array}$ & - \\
\hline \multicolumn{2}{|r|}{ Bilişsel Boyut } \\
\hline Alma & 12.1.1.1. Redoks tepkimelerini tanır. (Kimya) \\
\hline Kavrama & $\begin{array}{l}\text { 6.3.2.2. Yol, zaman ve sürat arasındaki ilişkiyi grafik üzerinde } \\
\text { gösterir. (Fen Bilimleri) }\end{array}$ \\
\hline Analiz & $\begin{array}{l}\text { 10.2.1.2. Genetik varyasyonların biyolojik çeşitliliği açıklamadaki } \\
\text { rolünü sorgular. (Biyoloji) }\end{array}$ \\
\hline Bilgiyi kullanma & $\begin{array}{l}\text { 8.5.1.2. Basit makinelerden yararlanarak günlük yaşamda iş kolaylığ } 1 \\
\text { sağlayacak bir düzenek tasarlar. (Fen Bilimleri) }\end{array}$ \\
\hline
\end{tabular}

\section{Verilerin analizi}

Araştırmadaki veriler, nitel araştırma yöntemlerinin analiz basamaklarından biri olan betimsel içerik analizi yardımıyla incelenmiştir. Betimsel analiz, toplanan ya da var olan nitel verinin araştırma soruları çerçevesinde belirlenen kodlar ve temalar altında toplanarak anlamlı hale getirilmesine olanak sağlamaktadır (Yıldırım ve Şimşek, 2016). Çalışmada araştırma sorularından oluşturulan çerçeve ile veriler belirli temalar altında düzenlenmiştir. Araştırmanın amacına hizmet eden veriler, belirlenen temalara yerleştirilirken, amaca hizmet etmeyenler temaların dışında kalmıştır. Her bir ders için öğretim programlarının kazanımları, sınıf seviyesi ve üniteler bazında detaylı olarak incelenmiş ve kazanımlar Marzano taksonomisinin bilişsel ve bilgi boyutlarına göre frekans ve yüzdelik değerler verilerek tablolaştırılmıştır.

\section{Geçerlik ve güvenirlik}

$\mathrm{Bu}$ çalışmada geçerlik ve güvenirlik için aşağıda ifade edilen adımlar uygulanmıştır. Nitel çalışmalar için geçerlik, araştırılan olay ve olgunun araştırmacı tarafından olduğu gibi ve tarafsız olarak yansıtılması demektir (Kirk ve Miller, 1986). Araştırmanın iç geçerliği noktasında, şu 
noktalar dikkate alınmıştır: Bulguların kendi içinde anlamlı ve tutarlılığı, ortaya çıkan kavramların anlamlı bir bütünlük içermesi, yapılan genellemelerin çalışma sonucuna götürecek verilerle tutarlılığı (Yıldırım ve Şimşek, 2016). Bu sorular doğrultusunda öğretim programlarındaki kazanımların Marzano'nun taksonomisindeki bilgi ve bilişsel boyutlarıyla ne kadar örtüştüğü incelenmiştir. Elde edilen son bulgular, iki eğitim uzmanı (program geliştirme ve ölçme-değerlendirme) ile paylaşılarak onların görüşleri alınmıştır. Ek olarak, çalışmaya katılan araştırmacılardan biri ilgili konu alanında yüksek lisans yapmış bir bilim uzmanı, diğer ikisi bu konuda yüksek lisans çalışması yaptırmış akademisyenlerden oluşmaktadır. Çalışma grubu kimya, fen bilimleri ve fizik alanında uzman araştırmacılardır. Kazanımları kodlayan üç araştırmacı arasındaki kodlayıcı uyum değeri (Fleiss'in kappa değeri) hesaplanmış ve 0,79 olarak bulunmuştur. Fleiss kappa değeri sınıflamasına göre bu değer ( 0,75 ve üzeri) kodlayıcılar arasında mükemmel bir uyum olduğunu göstermektedir (Fleiss, 1971).

Çalışmanın güvenirlik sağlama boyutunda, elde edilen bulguların uygunluğuna, benzer ortamlarda sonuçların genellenebilirliğine ve verilerin nesnel bir şekilde toplanarak sonuçların ortaya konulmasına bakılmıştır. Nitel bir araştırmada güvenirlik için elde edilen verilerin kapsamlı bir şekilde raporlanması ve araştırmacının bulgulara ulaşırken izlediği yolları ayrıntılı olarak vermesi önemli bir ölçüttür (Yıldırım ve Şimşek, 2016). Bu doğrultuda elde edilen veriler detaylı bir şekilde tablolaştırılmıştır.

\section{Bulgular}

Yapılan analizlere dayanarak elde edilen sonuçlar aşağıda detaylı olarak verilmiştir.

Tablo 2

2018 Ortaögretim Biyoloji Dersi Öğretim Programındaki Kazanımların Marzano Taksonomisinin Bilgi ve Bilişsel Süreç Boyutuna Göre Dağılımı

\begin{tabular}{|c|c|c|c|c|c|c|c|c|c|c|c|c|c|c|c|}
\hline \multirow[b]{2}{*}{$\stackrel{\leftarrow}{\Xi}$} & \multirow[b]{2}{*}{ : } & \multicolumn{6}{|c|}{ Bilgi } & \multicolumn{8}{|c|}{ Bilişsel } \\
\hline & & & $\frac{50}{\overline{0}}$ & & $\frac{\overrightarrow{0}}{\tilde{d}}$ & ڤ̄ & 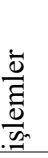 & & $\underset{\Xi}{\stackrel{\Xi}{Z}}$ & & 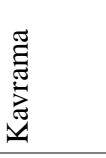 & & $\stackrel{N}{\stackrel{N}{J}}$ & & 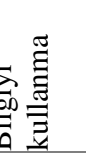 \\
\hline \multirow{5}{*}{9} & & $\mathrm{f}$ & $\%$ & $\mathrm{f}$ & $\%$ & $\mathrm{f}$ & $\%$ & $\mathrm{f}$ & $\%$ & $\mathrm{f}$ & $\%$ & $f$ & $\%$ & $f$ & $\%$ \\
\hline & 1 & 3 & 27,27 & - & - & - & - & 1 & 9,09 & 2 & 18,18 & - & - & - & - \\
\hline & 2 & 2 & 18,18 & 1 & 9,09 & - & - & 1 & 9,09 & 1 & 9,09 & 1 & 9,09 & - & - \\
\hline & 3 & 5 & 45,45 & - & - & - & - & 3 & 27,27 & 2 & 18,18 & - & - & - & - \\
\hline & TOPLAM & 10 & 90,90 & 1 & 9,09 & - & - & 5 & 45,45 & 5 & 45,45 & 1 & 9,09 & - & - \\
\hline \multirow{3}{*}{10} & 1 & - & - & 5 & 29,41 & - & - & - & - & 5 & 29,41 & - & - & - & - \\
\hline & 2 & 1 & 5,88 & 1 & 5,88 & - & - & - & - & 1 & 5,88 & 1 & 5,88 & - & - \\
\hline & 3 & 6 & 35,29 & 4 & 23,53 & - & - & - & - & 7 & 41,17 & 3 & 17,65 & - & - \\
\hline & TOPLAM & 7 & 41,17 & 10 & 58,82 & - & - & - & - & 13 & 76,46 & 4 & 23,53 & - & - \\
\hline \multirow[t]{4}{*}{11} & 1 & 18 & 52,94 & 11 & 32,35 & - & - & - & - & 21 & 61,76 & 8 & 23,53 & - & - \\
\hline & 2 & 5 & 14,70 & - & - & - & - & - & - & 4 & 11,76 & 1 & 2,94 & - & - \\
\hline & TOPLAM & 23 & 67,64 & 11 & 32,35 & - & - & - & - & 25 & 73,52 & 9 & 26,47 & - & - \\
\hline & 1 & 4 & 13,79 & 4 & 13,79 & - & - & 4 & 13,79 & 3 & 10,34 & 1 & 3,45 & - & - \\
\hline \multirow[t]{4}{*}{12} & 2 & - & - & 8 & 27,59 & - & - & - & - & 4 & 13,79 & 3 & 10,34 & 1 & 3,45 \\
\hline & 3 & 2 & 6,90 & 9 & 31,03 & - & - & - & - & 8 & 27,59 & - & - & 3 & 10,34 \\
\hline & 4 & 2 & 6,90 & - & - & - & - & - & - & 2 & 6,90 & - & - & - & - \\
\hline & TOPLAM & 8 & 27,59 & 21 & 72,41 & - & - & 4 & 13,79 & 17 & 58,62 & 4 & 13,79 & 4 & 13,79 \\
\hline \multicolumn{16}{|c|}{$\begin{array}{l}\text { 9. Sınıf-1: Yaşam bilimi biyoloji, 2: Hücre 3: Canlılar dünyası } \\
\text { 10. Sınıf-1: Hücre bölünmeleri, 2: Kalıtımın genel ilkeleri 3: Ekosistem ekolojisi ve güncel çevre sorunları } \\
\text { 11. Sınıf-1: İnsan fizyolojisi, 2: Komünite ve popülasyon ekolojisi } \\
\text { 12. Sınıf-1: Genden proteine, 2: Canlılarda enerji dönüşümleri, 3: Bitki biyolojisi, 4: Canlılar ve çevre }\end{array}$} \\
\hline
\end{tabular}


Ortaöğretim biyoloji dersi 9. sınıf programında toplam 11 kazanım yer almaktadır. Tablo 2'ye göre bu 11 kazanımdan \%90,90'1 (10 kazanım) bilgi basamağında, \%9,09'u (1 kazanım) zihinsel işlemler basamağında bulunmaktadır. Psikomotor bilgi kapsamında herhangi bir kazanım belirlenmemiştir. Bilişsel süreç boyutunda ise, 11 kazanımdan \%45,45'i (5 kazanım) alma, \%45,45'i (5 kazanım) kavrama ve \%9,09'u (1 kazanım) analiz basamağında bulunurken, bilgiyi kullanma basamağında herhangi bir kazanım yer almamaktadır.

Tablo 2'deki analiz sonuçlarına göre, 10. sınıf biyoloji dersi öğretim programındaki 17 kazanımdan bilgi boyutunda \%41,17'si (7 kazanım) bilgi, \%58,82'si (10 kazanım) zihinsel işlemler basamağındadır. Psikomotor bilgi boyutunda herhangi bir kazanım bulunamamıştır. Bilişsel süreç boyutunda ise, 17 kazanımdan \%76,46's1 (13 kazanım) kavrama, \%23,53'ü (4 kazanım) analiz basamağında yer almaktadır. Alma ve bilgiyi kullanma basamağında ise kazanım tespit edilememiştir.

11. sınıf biyoloji dersi öğretim programındaki toplam 34 kazanımdan bilgi boyutunda \%67,64’ü (23 kazanım) bilgi basamağında, \%32,35'i (11 kazanım) zihinsel işlemler basamağında yer alırken, psikomotor işlemler basamağında herhangi bir kazanım tespit edilememiştir. Bilişsel süreç boyutunda \%73,52'si (25 kazanım) kavrama, \%26,47'si (9 kazanım) analiz düzeyinde bulunmaktadır. Alma ve bilgiyi kullanma düzeyinde ise kazanım bulunmamaktadır.

Tablo 2'de görüldüğü gibi biyoloji dersi 12. sınıf öğretim programındaki 29 kazanım bilgi boyutunda incelendiğinde \%27,59'u (8 kazanım) bilgi basamağında yer alırken, \%72,41'i (21 kazanım) zihinsel işlemler basamağında yer almaktadır. Psikomotor bilgi düzeyinde ise kazanım belirlenmemiştir. Bilişsel süreç boyutunda incelendiğinde ise bu 29 kazanımdan \%13,79'u (4 kazanım) alma, \%58,62'si (17 kazanım) kavrama, \%13,79'u (4 kazanım) analiz ve yine aynı oranda $(\% 13,79)$ bilgiyi kullanma basamağında kazanım bulunmaktadır.

Bulgulara sınıf düzeyinde bakıldığında, biyoloji öğretim programında bilginin alanlarındaki bilgi boyutunda kazanım oranıen fazla 9. sinıftadır. Daha sonra sirasıyla 11. sinıf, 10. sinif ve 12. sinif gelmektedir. Zihinsel işlemler boyutunda ise 12. sınıf, en fazla oran ile birinci sırada yer almaktadır. İkinci sırada 10. sinıf, sonrasında ise 11. ve 9. sinıflar bulunmaktadır. Psikomotor işlemlere ait hiçbir sınıf seviyesinde kazanım yoktur. Bilişsel sistem bakımından ise alma düzeyinde 10. ve 11. sinıflarda kazanım bulunmazken, 9. sinıfta kazanım oranı en fazladır. Kavrama ve analiz düzeylerine en yoğun 11. sinıflarda rastlanmaktadır. 10. sinıf kavrama düzeyinde, 9. sınıf ise analiz düzeyinde en az kazanım yoğunluğa sahip sınıf seviyeleridir. Bilgiyi kullanma boyutunda ise 9, 10 ve 11. sınıf seviyelerinde bir kazanım bulunamamıştır.

9. sınıf fizik dersi öğretim programında toplam 44 kazanım yer almaktadır. Tablo 3'e göre bu 44 kazanımdan bilgi boyutunda \%31,82'si (14 kazanım) bilgi basamağında, \%68,19'u (30 kazanım) zihinsel işlemler basamağında yer alırken, psikomotor bilgi kapsamında kazanım belirlenmemiştir. Bilişsel süreç boyutunda ise \%25,01'i (11 kazanım) alma, \%54,55'i (24 kazanım) kavrama, \%15,91'i (7 kazanım) analiz basamağında ve \%4,55'i (2 kazanım) bilgiyi kullanma basamağında bulunmaktadır.

10. sınıf fizik dersi öğretim programında yer alan 39 kazanımdan bilgi boyutunda kazanımların \%35,90'1 (14 kazanım) bilgi, \%64,11'i (25 kazanım) zihinsel işlemler basamağında yer almaktadır. Psikomotor bilgi boyutunda ise herhangi bir kazanım bulunamamıştır. Bilişsel süreç boyutunda ise kazanımların \%28,21'i (11 kazanım) alma, \%53,84'ü (21 kazanım) kavrama, $\% 12,81$ 'i (5 kazanım) analiz ve \%5,12'si (2 kazanım) bilgiyi kullanma basamağında bulunduğu tespit edilmiştir. 
Tablo 3

2018 Ortaöğretim Fizik Dersi Öğretim Programındaki Kazanımların Marzano Taksonomisinin Bilgi ve Bilişsel Süreç Boyutuna Göre Dă̆ılımı

\begin{tabular}{|c|c|c|c|c|c|c|c|c|c|c|c|c|c|c|c|}
\hline \multirow[b]{2}{*}{$\begin{array}{l}\text { 亗 } \\
\stackrel{\Xi}{\omega}\end{array}$} & & \multicolumn{6}{|c|}{ Bilgi } & \multicolumn{8}{|c|}{ Bilişsel } \\
\hline & 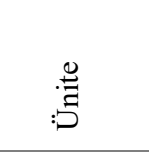 & & $\frac{50}{00}$ & & 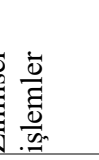 & & $\frac{\dot{0}}{\frac{\overrightarrow{0}}{\overrightarrow{0}}}$ & & $\frac{\widetilde{\Xi}}{\gtrless}$ & & 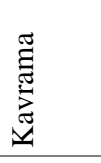 & & : & & 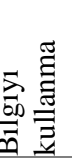 \\
\hline \multirow{8}{*}{9} & & $\mathrm{f}$ & $\%$ & $\mathrm{f}$ & $\%$ & $\mathrm{f}$ & $\%$ & $\mathrm{f}$ & $\%$ & $\mathrm{f}$ & $\%$ & $\mathrm{f}$ & $\%$ & $\mathrm{f}$ & $\%$ \\
\hline & 1 & 4 & 9,09 & - & - & - & - & 2 & 4,55 & 2 & 4,55 & - & - & - & - \\
\hline & 2 & 2 & 4,55 & 2 & 4,55 & - & - & 1 & 2,27 & 3 & 6,82 & - & - & - & - \\
\hline & 3 & 3 & 6,82 & 8 & 18,18 & - & - & 2 & 4,55 & 8 & 18,18 & 1 & 2,27 & - & - \\
\hline & 4 & 1 & 2,27 & 7 & 15,91 & - & - & 2 & 4,55 & 4 & 9,09 & 2 & 4,55 & - & - \\
\hline & 5 & 3 & 6,82 & 10 & 22,73 & - & - & 3 & 6,82 & 4 & 9,09 & 4 & 9,09 & 2 & 4,55 \\
\hline & 6 & 1 & 2,27 & 3 & 6,82 & - & - & 1 & 2,27 & 3 & 6,82 & - & - & - & - \\
\hline & TOPLAM & 14 & 31,82 & 30 & 68,19 & - & - & 11 & 25,01 & 24 & 54,55 & 7 & 15,91 & 2 & 4,55 \\
\hline \multirow{5}{*}{10} & 1 & 2 & 5,13 & 7 & 17,95 & - & - & 2 & 5,13 & 4 & 10,26 & 3 & 7,69 & - & - \\
\hline & 2 & - & - & 4 & 10,26 & - & - & - & - & 3 & 7,69 & - & - & 1 & 2,56 \\
\hline & 3 & 7 & 17,95 & 5 & 12,82 & - & - & 4 & 10,26 & 6 & 15,38 & 1 & 2,56 & 1 & 2,56 \\
\hline & 4 & 5 & 12,82 & 9 & 23,08 & - & - & 5 & 12,82 & 8 & 20,51 & 1 & 2,56 & - & - \\
\hline & TOPLAM & 14 & 35,90 & 25 & 64,11 & - & - & 11 & 28,21 & 21 & 53,84 & 5 & 12,81 & 2 & 5,12 \\
\hline \multirow{3}{*}{11} & 1 & 6 & 9,68 & 27 & 43,55 & - & - & 16 & 25,81 & 13 & 20,97 & 3 & 4,84 & 1 & 1,61 \\
\hline & 2 & 7 & 11,29 & 22 & 35,48 & - & - & 12 & 19,35 & 11 & 17,74 & 6 & 9,68 & - & - \\
\hline & TOPLAM & 13 & 20,97 & 49 & 79,03 & - & - & 28 & 45,16 & 24 & 38,71 & 9 & 14,52 & 1 & 1,61 \\
\hline \multirow{7}{*}{12} & 1 & 6 & 8,82 & 9 & 13,24 & - & - & 7 & 10,29 & 5 & 7,35 & 3 & 4,41 & - & - \\
\hline & 2 & - & - & 5 & 7,35 & - & - & 2 & 2,94 & 1 & 1,47 & 2 & 2,94 & - & - \\
\hline & 3 & - & - & 8 & 11,76 & - & - & - & - & 7 & 10,29 & 1 & 1,47 & - & - \\
\hline & 4 & 1 & 1,47 & 10 & 14,71 & - & - & 1 & 1,47 & 10 & 14,71 & - & - & - & - \\
\hline & 5 & 3 & 4,41 & 12 & 17,65 & - & - & 4 & 5,88 & 10 & 14,71 & 1 & 1,47 & - & - \\
\hline & 6 & 9 & 13,24 & 5 & 7,35 & - & & 4 & 5,88 & 8 & 11,76 & 1 & 1,47 & 1 & 1,47 \\
\hline & TOPLAM & 19 & 27,94 & 49 & 72,06 & - & - & 18 & 2646 & 41 & 6029 & 8 & 11,76 & 1 & 1,47 \\
\hline
\end{tabular}

Not. 9. Sınıf-1: Fizik bilimine giriş, 2: Madde ve özellikleri, 3: Hareket ve kuvvet, 4: Enerji, 5: Isı 10. Sınıf-1: Elektrik ve Manyetizma, 2: Basınç ve kaldırma kuvveti, 3: Dalgalar, 4: Optik

11. Sinıf-1: Kuvvet ve hareket, 2: Elektrik ve Manyetizma

12. Sınıf-1: Çembersel hareket, 2: Basit harmonic hareket, 3: Dalga mekaniği, 4: Atom fiziğine giriş ve radyoaktivite, 5: Modern fizik, 6: Modern fiziğin teknolojideki uygulamaları

Tablo 3’te görüldügü üzere 11. sinıftaki toplam 62 kazanımdan bilgi boyutunda \%20,97'si (13 kazanım) bilgi, \%79,03’ü (49 kazanım) zihinsel işlemler basamağında yer alırken, psikomotor işlemler basamağında herhangi bir kazanım tespit edilmemiştir. Bilişsel süreç boyutunda ise kazanımların \%45,16's1 (28 kazanım) alma, \%38,71'i (24 kazanım) kavrama, \%14,52'si (9 kazanım) analiz ve \%1,61'i (1 kazanım) bilgiyi kullanma basamağında yer almaktadır.

Tablo 3'e göre toplamda 68 kazanımı olan 12. sınıf programı bilgi boyutunda incelendiğinde, \%27,94'ü (19 kazanım) bilgi basamağında, \%72,06's1 (49 kazanım) zihinsel işlemler basamağında yer almaktadır. Psikomotor bilgi düzeyinde ise kazanım belirlenmemiştir. Bilişsel süreç boyutunda ise bu 68 kazanımdan \%26,46'sı (18 kazanım) alma, \%60,29'u (41 kazanım) kavrama, \%11,76'sı (8 kazanım) analiz ve \%1,47'si (1 kazanım) bilgiyi kullanma basamağında tespit edilmiştir.

Bulgulara sınıf düzeyinde bakıldığında, fizik öğretim programında bilginin alanlarındaki bilgi boyutunda kazanım oranı en fazla 10. sinıftadır. Daha sonra sirasiyla 9. sinıf, 12. sinıf ve 11. sinıf gelmektedir. Zihinsel işlemler boyutunda ise 11. sınıf en fazla oran ile birinci sırada yer almaktadır. İkinci sırada 12. sinıf, sonrasında ise 9. ve 10. sinıflar bulunmaktadır. Psikomotor işlemlere ait hiçbir sınıf seviyesinde kazanım yoktur. Bilişsel sistem bakımından ise alma 
düzeyinde 11. sınıfta kazanım oranı en fazladır. Kavrama ve analiz düzeylerine en yoğun olarak sirasıyla 12. ve 9. sinıflarda rastlanmaktadır. 11. sinıf kavrama düzeyinde, 12. sinıf ise analiz düzeyinde en az kazanım yoğunluğuna sahip sınıf seviyeleridir. Bilgiyi kullanma boyutunda ise oran en fazla 10. sinıftadır.

Tablo 4

2018 Ortaögretim Kimya Dersi Öğretim Programındaki Kazanımların Marzano Taksonomisinin Bilgi ve Bilişsel Süreç Boyutuna Göre Dağılımı Bilgi Bilişsel

\begin{tabular}{|c|c|c|c|c|c|c|c|c|c|c|c|c|c|c|c|}
\hline 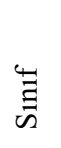 & 苞 & & $\frac{50}{\bar{m}}$ & & 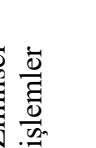 & & & & $\frac{\underset{\Xi}{\xi}}{\gtrless}$ & & 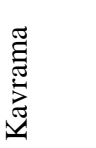 & & $\frac{N}{\stackrel{乛}{\mathcal{Z}}}$ & & స్ \\
\hline \multirow{7}{*}{9} & & $\mathrm{f}$ & $\%$ & $\mathrm{f}$ & $\%$ & $\mathrm{f}$ & $\%$ & $\mathrm{f}$ & $\%$ & $\mathrm{f}$ & $\%$ & $\mathrm{f}$ & $\%$ & $\mathrm{f}$ & $\%$ \\
\hline & 1 & 5 & 13,16 & 2 & 5,26 & - & - & 4 & 10,53 & 3 & 7,89 & - & - & - & - \\
\hline & 2 & - & - & 5 & 13,16 & - & - & 1 & 2,63 & 3 & 7,89 & 1 & 2,63 & - & - \\
\hline & 3 & 1 & 2,63 & 10 & 26,32 & - & - & 5 & 13,16 & 6 & 15,79 & - & - & - & - \\
\hline & 4 & 3 & 7,89 & 7 & 18,42 & - & - & 4 & 10,53 & 4 & 10,53 & 2 & 5,26 & - & - \\
\hline & 5 & 2 & 5,26 & 3 & 7,89 & - & - & 1 & 2,63 & 1 & 2,63 & 1 & 2,63 & 2 & 5,26 \\
\hline & TOPLAM & 11 & 28,94 & 27 & 71,05 & - & - & 15 & 39,48 & 17 & 44,73 & 4 & 10,52 & 2 & 5,26 \\
\hline \multirow{5}{*}{10} & 1 & 2 & 8,70 & 2 & 8,70 & - & - & 1 & 4,35 & 2 & 8,70 & 1 & 4,35 & - & - \\
\hline & 2 & - & - & 5 & 21,74 & - & - & - & - & 2 & 8,70 & 3 & 13,04 & - & - \\
\hline & 3 & - & - & 7 & 30,43 & - & - & - & - & 4 & 17,39 & 3 & 13,04 & - & - \\
\hline & 4 & 1 & 4,35 & 6 & 26,09 & - & - & - & - & 5 & 21,74 & 1 & 4,35 & 1 & 4,35 \\
\hline & TOPLAM & 3 & 13,05 & 20 & 86,96 & - & - & 1 & 4,35 & 13 & 56,53 & 8 & 34,78 & 1 & 4,35 \\
\hline \multirow{7}{*}{11} & 1 & - & - & 5 & 14,29 & - & - & - & - & 4 & 11,43 & 1 & 2,86 & - & - \\
\hline & 2 & 1 & 2,86 & 5 & 14,29 & - & - & 1 & 2,86 & 4 & 11,43 & 1 & 2,86 & - & - \\
\hline & 3 & 2 & 5,71 & 4 & 11,43 & - & - & - & - & 6 & 17,14 & - & - & - & - \\
\hline & 4 & - & - & 4 & 11,43 & - & - & - & - & 4 & 11,43 & - & - & - & - \\
\hline & 5 & - & - & 3 & 8,57 & - & - & - & - & 3 & 8,57 & - & - & - & - \\
\hline & 6 & - & - & 11 & 31,43 & - & - & - & - & 10 & 28,57 & 1 & 2,86 & - & - \\
\hline & TOPLAM & 3 & 8,57 & 32 & 91,44 & - & - & 1 & 2,86 & 31 & 88,57 & 3 & 8,58 & - & - \\
\hline \multirow{5}{*}{12} & 1 & 1 & 3,23 & 8 & 25,81 & - & - & 2 & 6,45 & 5 & 16,13 & 2 & 6,45 & - & - \\
\hline & 2 & - & - & 6 & 19,35 & - & - & 3 & 9,68 & 2 & 6,45 & 1 & 3,23 & - & - \\
\hline & 3 & - & - & 11 & 35,48 & - & - & 2 & 6,45 & 9 & 29,03 & - & - & - & - \\
\hline & 4 & 3 & 9,68 & 2 & 6,45 & - & - & 1 & 3,23 & - & - & 4 & 12,90 & - & - \\
\hline & TOPLAM & 4 & 12,91 & 27 & 87,09 & - & - & 8 & 25,81 & 16 & 51,61 & 7 & 22,58 & - & - \\
\hline \multicolumn{16}{|c|}{$\begin{array}{l}\text { 9. Sınıf-1: Kimya bilimi, 2: Atom ve periyodik system, 3: Kimyasal türler arası etkileşimler, 4: Maddenin halleri, } \\
\text { 5: Doğa ve kimya } \\
\text { 10. Sınıf-1: Kimyanın temel kanunları ve kimyasal hesaplamalar, 2: Karışımlar, 3: Asitler, bazlar ve tuzlar 4: Kimya } \\
\text { her yerde } \\
\text { 11. Sınıf-1: Modern atom teorisi, 2: Gazlar, 3: Sıvı çözeltiler ve çözünürlük, 4: Kimyasal tepkimelerde enerji, } 5 \\
\text { Kimyasal tepkimelerde hız, 6: Kimyasal tepkimelerde denge } \\
\text { 12. Sınıf-1: Kimya ve elektrik, 2: Karbon kimyasına giriş, 3: Organik bileşikler, 4: Enerji kaynakları ve bilimse } \\
\text { gelişmeler }\end{array}$} \\
\hline
\end{tabular}

Tablo 4'te görüldüğ̈̈ gibi, 9. sınıf kimya dersi öğretim programındaki 38 kazanıma bilgi boyutu altında bakıldığında, \%28,94'ü (11 kazanım) bilgi boyutunda, \%71,05'i (27 kazanım) zihinsel işlemler boyutunda olup, psikomotor işlemlere ait bir kazanım saptanmamıştır. Bilişsel süreç boyutu açısından incelendiğinde, \%39,48'i (15 kazanım) alma, \%44,73’ü (17 kazanım) kavrama, \%10,52'si (4 kazanım) analiz ve \%5,26'si (2 kazanım) bilgiyi kullanma boyutlarından oluşmaktadır.

10. sinıf kimya programında yer alan 23 kazanımdan, \%13,05'i (3 kazanım) bilgi, \%86,96's1 (20 kazanım) zihinsel işlemler boyutundan oluşmaktadır. Psikomotor işlemler boyutunda ise herhangi bir kazanım bulunamamıştır. Bilişsel süreç boyutunda ise \%4,35'i (1 kazanım) alma, \%56,53'ü 
(13 kazanım) kavrama, \%34,78'i (8 kazanım) analiz ve \%4,35'i (1 kazanım) bilgiyi kullanma basamağında yer almaktadır.

Tablo 4 dikkate alındığında, bilgi boyutu dağılımı analizine göre 11. sınıf kazanımlarının \%8,57'sini (3 kazanım) bilgi basamağında, \%91,44'ü (32 kazanım) zihinsel işlemler basamağında bulunmaktadır. Psikomotor işlemlerde herhangi bir kazanımın yer almadığı görülmektedir. Bilişsel boyut açısından incelendiğinde ise, toplam 35 kazanımın \%2,86'sı (1 kazanım) alma, \%88,57'si (31 kazanım) kavrama, \%8,58'i (3 kazanım) analiz basamağında yer almaktadır. Bilgiyi kullanma basamağına giren bir kazanım ise tespit edilmemiştir.

12. sınıf kimya programındaki 31 kazanımın bilgi boyutundaki dağılımına bakıldığı zaman, \%12,91'i (4 kazanım) bilgi basamağını kapsarken, \%87,09'u (27 kazanım) zihinsel işlemler basamağını içermektedir. Psikomotor işlemlere giren bir kazanım yoktur. 12. sınıf kimya dersi öğretim programında bulunan toplam 31 kazanımın \%25,81'i (8 kazanım) alma, \%51,61'i (16 kazanım) kavrama, \%22,58'i (7 kazanım) analiz basamağında bulunmaktadır. Bilgiyi kullanma basamağında herhangi bir kazanım ise tespit edilmemiştir.

Bulgulara sınıf düzeyinde bakıldığında, kimya öğretim programında bilginin alanlarındaki bilgi boyutunda kazanım oranı en fazla 9. sinıftadır. Daha sonra sirasıyla 10. sinıf, 12. sinıf ve 11. sinif gelmektedir. Zihinsel işlemler boyutunda ise 11. sınıf en fazla oran ile birinci sırada yer almaktadır. İkinci sırada 12. sınıf, sonrasında ise 10. ve 9. sinıflar bulunmaktadır. Psikomotor işlemlere ait hiçbir sınıf seviyesinde kazanım yoktur. Bilişsel sistem bakımından ise alma düzeyinde 9. sınıfta kazanım oranı en fazladır. Kavrama ve analiz düzeylerine ait kazanımlara en yoğun sirasiyla 12. ve 10. sinıflarda rastlanmaktadır. 9. sinıf kavrama düzeyinde, 11. sinıf ise analiz düzeyinde en az kazanım yoğunluğa sahip sınıf seviyeleridir. Bilgiyi kullanma boyutunda ise 9. ve 10. sinıf seviyelerinde kazanım bulunurken, 11. ve 12. sinıf seviyelerinde ise bir kazanım bulunamamıştır.

4. sınıfta yer alan 43 kazanımın bilgi boyutunda \%65,12'si (28 kazanım) bilgi, \%34,90'u (15 kazanım) zihinsel işlemler basamağında yer alırken, psikomotor bilgi boyutunda kazanım bulunmamıştır. Bilişsel süreç boyutundaki analiz sonuçlarına göre ise kazanımların \%34,90’1 (15 kazanım) alma, \%65,12'si (28 kazanım) kavrama basamağında yer almaktadır. Analiz ve bilgiyi kullanma basamağında herhangi bir kazanım bulunmamıştır.

Tablo 5'teki verilere göre 5. sınıf seviyesindeki 36 kazanımdan, \%47,23'ü (17 kazanım) bilgi basamağında, \%52,78'i (19 kazanım) zihinsel işlemler basamağında yer alırken, psikomotor bilgi kapsamında kazanım belirlenmemiştir. Bilişsel süreç boyutunda ise kazanımların \%16,68'i (6 kazanım) alma, \%55,56'sı (20 kazanım) kavrama, \%19,45'i (7 kazanım) analiz ve \%8,34'ü (3 kazanım) bilgiyi kullanma basamağında yer almaktadır.

Yapılan analiz sonuçlarına göre 6. sınıf seviyesindeki 59 kazanımdan, bilgi boyutunda \%32,16's1 (19 kazanım) bilgi, \%67,74’ü (40 kazanım) zihinsel işlemler basamağında yer alırken, psikomotor bilgi boyutunda kazanım bulunmamıştır. Bilişsel süreç boyutlarına göre ise kazanımların \%20,31'i (12 kazanım) alma, \%67,75'i (40 kazanım) kavrama, \%8,46's1 (5 kazanım) analiz ve \%3,38’i (2 kazanım) bilgiyi kullanma basamağında bulunduğu tespit edilmiştir. 
Ortaöğretim Biyoloji, Fizik, Kimya ve Fen Bilimleri Derslerine Ait Öğretim Programlarının Marzano Taksonomisine Göre Analizi

Tablo 5 .

2018 Fen Bilimleri Öğretim Programındaki Kazanımların Marzano Taksonomisinin Bilgi ve Bilişsel Süreç Boyutuna Göre Dağılımı

Bilgi Bilişsel

\begin{tabular}{|c|c|c|c|c|c|c|c|c|c|c|c|c|c|c|c|}
\hline$\stackrel{\text { 岁 }}{\Xi}$ & 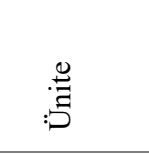 & & $\overline{00}$ & & $\frac{\vec{\omega}}{\vec{E}}$ & & & & $\frac{\mathbb{\Xi}}{\mathbb{\Xi}}$ & & 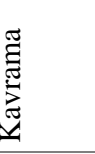 & & : & & 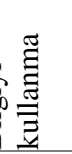 \\
\hline \multirow{9}{*}{3} & & f & $\%$ & $\mathrm{f}$ & $\%$ & $\mathrm{f}$ & $\%$ & $\mathrm{f}$ & $\%$ & f & $\%$ & f & $\%$ & $\mathrm{f}$ & $\%$ \\
\hline & 1 & 3 & 8,33 & 2 & 5,56 & - & - & 2 & 5,56 & 3 & 8,33 & - & - & - & - \\
\hline & 2 & 3 & 8,33 & - & - & - & - & 2 & 5,56 & 1 & 2,78 & - & - & - & - \\
\hline & 3 & 1 & 2,78 & 3 & 8,33 & - & - & - & - & 4 & 11,11 & - & - & - & - \\
\hline & 4 & 4 & 11,11 & - & - & - & - & 1 & 2,78 & 3 & 8,33 & - & - & - & - \\
\hline & 5 & 7 & 19,44 & 1 & 2,78 & - & - & 6 & 16,67 & 2 & 5,56 & - & - & - & - \\
\hline & 6 & 5 & 13,89 & 3 & 8,33 & - & - & 4 & 11,11 & 4 & 11,11 & - & - & - & - \\
\hline & 7 & 4 & 11,11 & - & - & - & - & 2 & 5,56 & 2 & 5,56 & - & - & - & - \\
\hline & TOPLAM & 27 & 74,99 & 9 & 25,00 & - & - & 17 & 47,24 & 19 & 52,78 & - & - & - & - \\
\hline \multirow{8}{*}{4} & 1 & 5 & 11,63 & - & - & - & - & 5 & 11,63 & - & - & - & - & - & - \\
\hline & 2 & 3 & 6,98 & 3 & 6,98 & - & - & 1 & 2,33 & 5 & 11,63 & - & - & - & - \\
\hline & 3 & 1 & 2,33 & 4 & 9,30 & - & - & 1 & 2,33 & 4 & 9,30 & - & - & - & - \\
\hline & 4 & 7 & 16,28 & 3 & 6,98 & - & - & 5 & 11,63 & 5 & 11,63 & - & - & - & - \\
\hline & 5 & 8 & 18,60 & 4 & 9,30 & - & - & 2 & 4,65 & 10 & 23,26 & - & - & - & - \\
\hline & 6 & 2 & 4,65 & - & - & - & - & - & - & 2 & 4,65 & - & - & - & - \\
\hline & 7 & 2 & 4,65 & 1 & 2,33 & - & - & 1 & 2,33 & 2 & 4,65 & - & - & - & - \\
\hline & TOPLAM & 28 & 65,12 & 15 & 34,90 & - & - & 15 & 34,90 & 28 & 65,12 & - & - & - & - \\
\hline \multirow{8}{*}{5} & 1 & 4 & 11,11 & 3 & 8,33 & - & - & 2 & 5,56 & 5 & 13,89 & - & - & - & - \\
\hline & 2 & 1 & 2,78 & - & - & - & - & - & - & 1 & 2,78 & - & - & - & - \\
\hline & 3 & 1 & 2,78 & 4 & 11,11 & - & - & 1 & 2,78 & 3 & 8,33 & - & - & 1 & 2,78 \\
\hline & 4 & 1 & 2,78 & 5 & 13,89 & - & - & - & - & 2 & 5,56 & 2 & 5,56 & 2 & 5,56 \\
\hline & 5 & 1 & 2,78 & 5 & 13,89 & - & - & 1 & 2,78 & 4 & 11,11 & 1 & 2,78 & - & - \\
\hline & 6 & 8 & 22,22 & - & - & - & - & 1 & 2,78 & 4 & 11,11 & 3 & 8,33 & - & - \\
\hline & 7 & 1 & 2,78 & 2 & 5,56 & - & - & 1 & 2,78 & 1 & 2,78 & 1 & 2,78 & - & - \\
\hline & TOPLAM & 17 & 47,23 & 19 & 52,78 & - & - & 6 & 16,68 & 20 & 55,56 & 7 & 19,45 & 3 & 8,34 \\
\hline \multirow{8}{*}{6} & 1 & 1 & 1,69 & 4 & 6,77 & - & - & - & - & 5 & 8,47 & - & - & - & - \\
\hline & 2 & 5 & 8,47 & 6 & 10,16 & - & - & 3 & 5,08 & 8 & 13,55 & - & - & - & - \\
\hline & 3 & 1 & 1,69 & 4 & 6,77 & - & - & 1 & 1,69 & 4 & 6,77 & - & - & - & - \\
\hline & 4 & 5 & 8,47 & 8 & 13,55 & - & - & 3 & 5,08 & 6 & 10,16 & 4 & 6,77 & - & - \\
\hline & 5 & 1 & 1,69 & 8 & 13,55 & - & - & 4 & 6,77 & 4 & 6,77 & - & - & 1 & 1,69 \\
\hline & 6 & 4 & 6,77 & 7 & 11,86 & - & - & - & - & 10 & 16,95 & - & - & 1 & 1,69 \\
\hline & 7 & 2 & 3,38 & 3 & 5,08 & - & - & 1 & 1,69 & 3 & 5,08 & 1 & 1,69 & - & - \\
\hline & TOPLAM & 19 & 32,16 & 40 & 67,74 & - & - & 12 & 20,31 & 40 & 67,75 & 5 & 8,46 & 2 & 3,38 \\
\hline \multirow{8}{*}{7} & 1 & 5 & 7,57 & 5 & 7,57 & - & - & 5 & 7,57 & 5 & 7,57 & - & - & - & - \\
\hline & 2 & 4 & 6,06 & 4 & 6,06 & - & - & 2 & 3,03 & 6 & 9,09 & - & - & - & - \\
\hline & 3 & 3 & 4,55 & 5 & 7,57 & - & - & 1 & 1,52 & 6 & 9,09 & - & - & 1 & 1,52 \\
\hline & 4 & 7 & 10,60 & 8 & 12,12 & - & - & 5 & 7,57 & 8 & 12,12 & - & - & 2 & 3,03 \\
\hline & 5 & 1 & 1,52 & 11 & 16,67 & - & - & 1 & 1,52 & 7 & 10,60 & 3 & 4,55 & 1 & 1,52 \\
\hline & 6 & - & - & 7 & 10,60 & - & - & - & - & 5 & 7,57 & 1 & 1,52 & 1 & 1,52 \\
\hline & 7 & 1 & 1,52 & 5 & 7,58 & - & - & 1 & 1,52 & 3 & 4,55 & 1 & 1,52 & 1 & 1,52 \\
\hline & TOPLAM & 21 & 31,82 & 45 & 68,17 & - & - & 15 & 22,73 & 40 & 60,59 & 5 & 7,59 & 6 & 9,11 \\
\hline
\end{tabular}


Çelikkaya, Oktay, Yazar, Bayrakçeken ve Canpolat

Tablo 5 (devami)

Bilgi

Bilişsel

\begin{tabular}{|c|c|c|c|c|c|c|c|c|c|c|c|c|c|c|c|}
\hline$\stackrel{4}{\Xi}$ & 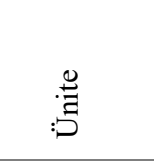 & & $\frac{\bar{D}}{\overline{0}}$ & & 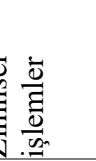 & & $\frac{\dot{\bar{d}}}{\frac{\overrightarrow{0}}{. \sqrt{n}}}$ & & $\begin{array}{l}\stackrel{\widetilde{g}}{\mathrm{E}} \\
\end{array}$ & & 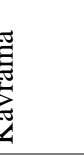 & 疍 & & & \\
\hline \multirow{9}{*}{3} & & $\mathrm{f}$ & $\%$ & $\mathrm{f}$ & $\%$ & $\mathrm{f}$ & $\%$ & $\mathrm{f}$ & $\%$ & $\mathrm{f}$ & $\%$ & $\mathrm{f}$ & $\%$ & $\mathrm{f}$ & $\%$ \\
\hline & 1 & 3 & 8,33 & 2 & 5,56 & - & - & 2 & 5,56 & 3 & 8,33 & - & - & - & - \\
\hline & 2 & 3 & 8,33 & - & - & - & - & 2 & 5,56 & 1 & 2,78 & - & - & - & - \\
\hline & 3 & 1 & 2,78 & 3 & 8,33 & - & - & - & - & 4 & 11,11 & - & - & - & - \\
\hline & 4 & 4 & 11,11 & - & - & - & - & 1 & 2,78 & 3 & 8,33 & - & - & - & - \\
\hline & 5 & 7 & 19,44 & 1 & 2,78 & - & - & 6 & 16,67 & 2 & 5,56 & - & - & - & - \\
\hline & 6 & 5 & 13,89 & 3 & 8,33 & - & - & 4 & 11,11 & 4 & 11,11 & - & - & - & - \\
\hline & 7 & 4 & 11,11 & - & - & - & - & 2 & 5,56 & 2 & 5,56 & - & - & - & - \\
\hline & TOPLAM & 27 & 74,99 & 9 & 25,00 & - & - & 17 & 47,24 & $\begin{array}{l}1 \\
9\end{array}$ & 52,78 & - & - & - & - \\
\hline \multirow{8}{*}{4} & 1 & 5 & 11,63 & - & - & - & - & 5 & 11,63 & - & - & - & - & - & - \\
\hline & 2 & 3 & 6,98 & 3 & 6,98 & - & - & 1 & 2,33 & 5 & 11,63 & - & - & - & - \\
\hline & 3 & 1 & 2,33 & 4 & 9,30 & - & - & 1 & 2,33 & 4 & 9,30 & - & - & - & - \\
\hline & 4 & 7 & 16,28 & 3 & 6,98 & - & - & 5 & 11,63 & 5 & 11,63 & - & - & - & - \\
\hline & 5 & 8 & 18,60 & 4 & 9,30 & - & - & 2 & 4,65 & $\begin{array}{l}1 \\
0\end{array}$ & 23,26 & - & - & - & - \\
\hline & 6 & 2 & 4,65 & - & - & - & - & - & - & 2 & 4,65 & - & - & - & - \\
\hline & 7 & 2 & 4,65 & 1 & 2,33 & - & - & 1 & 2,33 & 2 & 4,65 & - & - & - & - \\
\hline & TOPLAM & 28 & 65,12 & 15 & 34,90 & - & - & 15 & 34,90 & $\begin{array}{l}2 \\
8\end{array}$ & 65,12 & - & - & - & - \\
\hline \multirow{8}{*}{5} & 1 & 4 & 11,11 & 3 & 8,33 & - & - & 2 & 5,56 & 5 & 13,89 & - & - & - & - \\
\hline & 2 & 1 & 2,78 & - & - & - & - & - & - & 1 & 2,78 & - & - & - & - \\
\hline & 3 & 1 & 2,78 & 4 & 11,11 & - & - & 1 & 2,78 & 3 & 8,33 & - & - & 1 & 2,78 \\
\hline & 4 & 1 & 2,78 & 5 & 13,89 & - & - & - & - & 2 & 5,56 & 2 & 5,56 & 2 & 5,56 \\
\hline & 5 & 1 & 2,78 & 5 & 13,89 & - & - & 1 & 2,78 & 4 & 11,11 & 1 & 2,78 & - & - \\
\hline & 6 & 8 & 22,22 & - & - & - & - & 1 & 2,78 & 4 & 11,11 & 3 & 8,33 & - & - \\
\hline & 7 & 1 & 2,78 & 2 & 5,56 & - & - & 1 & 2,78 & 1 & 2,78 & 1 & 2,78 & - & - \\
\hline & TOPLAM & 17 & 47,23 & 19 & 52,78 & - & - & 6 & 16,68 & $\begin{array}{l}2 \\
0 \\
\end{array}$ & 55,56 & 7 & $\begin{array}{c}19,4 \\
5\end{array}$ & 3 & 8,34 \\
\hline \multirow{8}{*}{6} & 1 & 1 & 1,69 & 4 & 6,77 & - & - & - & - & 5 & 8,47 & - & - & - & - \\
\hline & 2 & 5 & 8,47 & 6 & 10,16 & - & - & 3 & 5,08 & 8 & 13,55 & - & - & - & - \\
\hline & 3 & 1 & 1,69 & 4 & 6,77 & - & - & 1 & 1,69 & 4 & 6,77 & - & - & - & - \\
\hline & 4 & 5 & 8,47 & 8 & 13,55 & - & - & 3 & 5,08 & 6 & 10,16 & 4 & 6,77 & - & - \\
\hline & 5 & 1 & 1,69 & 8 & 13,55 & - & - & 4 & 6,77 & 4 & 6,77 & - & - & 1 & 1,69 \\
\hline & 6 & 4 & 6,77 & 7 & 11,86 & - & - & - & - & $\begin{array}{l}1 \\
0\end{array}$ & 16,95 & - & - & 1 & 1,69 \\
\hline & 7 & 2 & 3,38 & 3 & 5,08 & - & - & 1 & 1,69 & 3 & 5,08 & 1 & 1,69 & - & - \\
\hline & TOPLAM & 19 & 32,16 & 40 & 67,74 & - & - & 12 & 20,31 & $\begin{array}{l}4 \\
0 \\
\end{array}$ & 67,75 & 5 & 8,46 & 2 & 3,38 \\
\hline \multirow{8}{*}{7} & 1 & 5 & 7,57 & 5 & 7,57 & - & - & 5 & 7,57 & 5 & 7,57 & - & - & - & - \\
\hline & 2 & 4 & 6,06 & 4 & 6,06 & - & - & 2 & 3,03 & 6 & 9,09 & - & - & - & - \\
\hline & 3 & 3 & 4,55 & 5 & 7,57 & - & - & 1 & 1,52 & 6 & 9,09 & - & - & 1 & 1,52 \\
\hline & 4 & 7 & 10,60 & 8 & 12,12 & - & - & 5 & 7,57 & 8 & 12,12 & - & - & 2 & 3,03 \\
\hline & 5 & 1 & 1,52 & 11 & 16,67 & - & - & 1 & 1,52 & 7 & 10,60 & 3 & 4,55 & 1 & 1,52 \\
\hline & 6 & - & - & 7 & 10,60 & - & - & - & - & 5 & 7,57 & 1 & 1,52 & 1 & 1,52 \\
\hline & 7 & 1 & 1,52 & 5 & 7,58 & - & - & 1 & 1,52 & 3 & 4,55 & 1 & 1,52 & 1 & 1,52 \\
\hline & TOPLAM & 21 & 31,82 & 45 & 68,17 & - & - & 15 & 22,73 & $\begin{array}{l}4 \\
0\end{array}$ & 60,59 & 5 & 7,59 & 6 & 9,11 \\
\hline
\end{tabular}


Tablo 5 (devam1)

\begin{tabular}{|c|c|c|c|c|c|c|c|c|c|c|c|c|c|c|c|}
\hline \multirow[b]{2}{*}{ 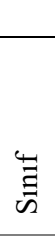 } & & \multicolumn{6}{|c|}{ Bilgi } & \multicolumn{8}{|c|}{ Bilişsel } \\
\hline & 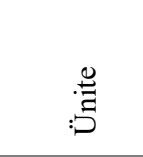 & & $\overline{00}$ & & $\frac{\vec{\sigma}}{\vec{\Xi}}$ & & & & $\frac{\tilde{g}}{\xi}$ & & 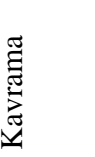 & & 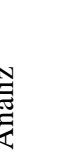 & & 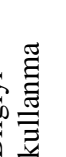 \\
\hline \multirow{9}{*}{8} & & $f$ & $\%$ & $\mathrm{f}$ & $\%$ & $f$ & $\%$ & $\mathrm{f}$ & $\%$ & $f$ & $\%$ & $\mathrm{f}$ & $\%$ & $\mathrm{f}$ & $\%$ \\
\hline & 1 & 2 & 3,33 & 1 & 1,67 & - & - & 2 & 3,33 & 1 & 1,67 & - & - & - & - \\
\hline & 2 & 5 & 8,33 & 8 & 13,33 & - & - & 2 & 3,33 & 10 & 16,67 & 1 & 1,67 & - & - \\
\hline & 3 & - & - & 3 & 5,00 & - & - & - & - & 3 & 5,00 & - & - & - & - \\
\hline & 4 & 9 & 15,00 & 8 & 13,33 & - & - & 4 & 6,67 & 11 & 18,33 & 2 & 3,33 & - & - \\
\hline & 5 & - & - & 2 & 3,33 & - & - & - & - & 1 & 1,67 & - & - & 1 & 1,67 \\
\hline & 6 & 6 & 10,00 & 6 & 10,00 & - & - & - & - & 9 & 15,00 & - & - & 3 & 5,00 \\
\hline & 7 & 3 & 5,00 & 7 & 11,67 & - & - & 1 & 1,67 & 9 & 15,00 & - & - & - & - \\
\hline & TOPLAM & 25 & 41,66 & 35 & 58,33 & - & - & 9 & 15,00 & 44 & 73,34 & 3 & 5,00 & 4 & 6,67 \\
\hline
\end{tabular}

3. Sınıf-1: Gezegenimizi tanıyalım, 2: Beş duyumuz, 3: Kuvveti tanıyalım, 4: Maddeyi tanıyalım, 5: Çevremizdeki 1şık ve sesler, 6: Canlılar dünyasına yolculuk, 7: Elektrikli araçlar

4. Sınıf-1: Yer kabuğu ve Dünya'mızın hareketleri, 2: Besinlerimiz, 3: Kuvvetin etkileri, 4: Maddenin özellikleri, 5: Aydınlatma ve ses teknolojileri, 6: İnsan ve çevre, 7: Basit elektrik devreleri

5. Sınıf-1: Güneş, Dünya ve Ay, 2: Canlılar dünyası, 3: Kuvvetin ölçülmesi ve sürtünme, 4: Madde ve değişim, 5: Işığın yayılması, 6: İnsan ve çevre, 7: Elektrik devre elemanları

6. Sınıf-1: Güneş sistemi ve tutulmalar, 2: Vücudumuzdaki sistemler, 3: Kuvvet ve hareket, 4: Madde ve 1S1, 5: Ses ve özellikleri, 6: Vücudumuzdaki sistemler ve sağlığı, 7: Elektriğin iletimi

7. Sınıf-1: Güneş sistemi ve ötesi, 2: Hücre ve bölünmeler, 3: Kuvvet ve enerji, 4: Saf madde ve karışımlar, 5: Işı̆̆ın madde ile etkileşimi, 6: Canlılarda üreme, büyüme ve gelişme, 7: Elektriğin devreleri

8. Sınıf-1: Mevsimler ve iklim, 2: DNA ve genetik kod, 3: Basınç, 4: Madde ve endüstri, 5: Basit makineler, 6:

Enerji dönüşümleri ve çevre bilimi, 7: Elektrik yükleri ve elektrik enerjisi

8. sınıf fen bilimleri dersi öğretim programında toplam 61 kazanım bulunmaktadır. Bu çalışma kapsamında Marzano taksonomisinin sadece bilgi ve bilişsel boyutları dikkate alındığından, 7. sınıf fen bilimleri dersi öğretim programına benzer olarak bir kazanım duyuşsal boyuta dâhil olduğu için inceleme 60 kazanım üzerinden yapılmıştır. Çıkarılan kazanım "Enerji Dönüşümleri ve Çevre Bilimi/Canlılar ve Yaşam” ünitesinin "Kaynakların kullanımında tasarruflu davranmaya özen gösterir." kazanımına aittir. Tablo 5'e göre kazanımların \%41,66's1 (25 kazanım) bilgi basamağında, \%58,33’ü (35 kazanım) zihinsel işlemler basamağında yer almaktadır. Psikomotor bilgi düzeyinde ise kazanım belirlenmemiştir. Bilişsel süreç boyutunda ise bu 60 kazanımdan \%15,00’i (9 kazanım) alma, \%73,34’ü (44 kazanım) kavrama, \%5,00’i (3 kazanım) analiz ve $\% 6,67$ 'si (4 kazanım) bilgiyi kullanma basamağında yer almaktadır.

Bulgulara sınıf düzeyinde bakıldığında, fen bilimleri dersi öğretim programında bilginin alanlarındaki bilgi boyutunda kazanım oranı en fazla 3. sınıftadır. Daha sonra sırasıyla 4. sınıf, 5 . sınıf, 6. sınıf ve 7. sınıf gelmektedir. Zihinsel işlemler boyutunda ise 7. sinıf, en fazla oran ile birinci sırada yer almaktadır. İkinci sırada 6. sinıf, sonrasinda ise 8. 5. 4. ve 3. siniflar bulunmaktadır. Psikomotor işlemlere ait hiçbir sınıf seviyesinde kazanım yoktur. Bilişsel sistem bakımından ise alma düzeyinde 3. sinıfta kazanım oranı en fazladır. Kavrama ve analiz düzeylerine en yoğun sırasıyla 8 . sınıf ve 5. sınıflarda rastlanmaktadır. 3. ve 4. sınıflar seviyesinde analiz düzeyinde bir kazanım yoktur. 3. sınıf kavrama düzeyinde, 8 . sınıf ise analiz düzeyinde en az kazanım yoğunluğa sahip sınıf seviyeleridir. Bilgiyi kullanma boyutunda ise 7. sınıf en fazla kazanıma sahiptir. 3. ve 4. sınıf seviyelerinde bu boyutta bir kazanım bulunamamıştır.

\section{Tartışma, Sonuç ve Öneriler}

Kazanımların bilişsel sınıflandırılmasının önemi göz önüne alınarak, bu çalışma dahilinde Marzano tarafından önerilen son taksonomiye göre ortaöğretim biyoloji, fizik, kimya ve fen bilimleri derslerine ait öğretim programlarındaki kazanımlar incelenmiştir. Araştırma kapsamında taksonominin sadece bilgi ve bilişsel süreç boyutları ele alınmıştır. 
Ortaöğretim biyoloji dersi $(9,10,11$ ve 12. sinıflar) öğretim programında toplam 12 ünite dahilinde 91 kazanım analiz edilmiştir. Bu kazanımların Marzano taksonomisinin bilgi boyutuna göre dağılımına bakıldığ 1 zaman, 9. ve 11. sınıf seviyelerinde kazanımların en fazla bilgi basamağında $(\% 90,90, \% 67,64), 10$. ve 12. sinıf seviyelerinde ise en fazla zihinsel işlemler basamağında $(\% 58,82, \% 72,41)$ bulunduğu tespit edilmiştir. Bilişsel süreç boyutunda ise kazanımlar 9. sınıf seviyesinde en fazla alma $(\% 45,45)$ ve kavrama basamağında $(\% 45,45)$ yer almıştır. Kavrama basamağı olarak en fazla oran 11. sınıfta $(\% 73,52)$, sonra ise sırasıyla 12. $(\% 58,62)$ ve 10 . sinıfta $(\% 41,17)$ gözlenmiştir.

Ortaöğretim fizik dersi $(9,10,11$ ve 12. sinıflar) öğretim programında toplam 18 ünitede 213 kazanım incelenmiştir. Bu kazanımların Marzano taksonomisinin bilgi boyutuna göre dağılımına bakıldığı zaman, 9, 10, 11 ve 12. sinıf seviyelerinde en fazla zihinsel işlemler basamağında $(\% 68,19, \% 64,11, \% 79,03, \% 72,06)$ kazanımların olduğu tespit edilmiştir. Bilişsel süreç boyutunda ise 9 . 10. ve 12 . sinıf seviyelerinde en fazla kavrama basamağında (\%54,55, \%53,84, $\% 60,29)$, 11. sinıf seviyesinde ise en fazla alma basamağında $(\% 45,16)$ kazanım olduğu bulunmuştur.

Ortaöğretim kimya dersi $(9,10,11$ ve 12 . sinıflar) öğretim programında 19 ünite içeriğinde toplam 127 kazanım dikkate alınmıştır. Bu kazanımların Marzano taksonomisinin bilgi boyutuna göre dağılımına bakıldığı zaman, 9, 10, 11 ve 12. sınıf seviyelerinde en fazla zihinsel işlemler basamağında $(\% 71,05, \% 86,96, \% 91,44, \% 87,09)$ kazanım bulunmuştur. Bilişsel süreç boyutunda ise $9,10,11$ ve 12 . sinıf seviyelerinde en fazla kavrama basamağında $(\% 44,73$, $\% 56,53, \% 88,57, \% 51,61)$ kazanım bulunduğu tespit edilmiştir. 2018 ortaöğretim kimya dersinin Bloom taksonomisine göre analiz edildiği bir çalışmada, bilişsel alanın alt basamaklarına (bilgi, kavrama) giren kazanımların daha fazla olduğu ve sınıf bazında homojenlik göstermediği görülmüştür. Ek olarak, bu çalışmadaki sonuçla benzer olarak bütün sınıf düzeylerinde en fazla kavrama basamağında kazanım saptanmıştır (Ayyıldız, Aydın ve Nakiboğlu, 2019).

Fen bilimleri dersi $(3,4,5,6,7$ ve 8 . sınıflar) öğretim programında 42 ünite içerisinde toplam 300 kazanım değerlendirilmiştir. Bu kazanımların Marzano taksonomisinin bilgi boyutuna göre dağılımına bakıldığı zaman, 3. ve 4. sınıf seviyelerinde en fazla bilgi basamağında (\%74,99, $\% 65,12), 5,6,7$ ve 8.sınıf seviyelerinde ise en fazla zihinsel işlemler basamağında $(\% 52,78$, $\% 67,74, \% 68,17, \% 58,33$ ) kazanıma rastlanmıştır. Bilişsel süreç boyutunda ise, 3, 4, 5, 6, 7 ve 8 . sinıf seviyelerinde en fazla kavrama basamağında (\%52,78, \%65,12, \%55,56, \%67,75, \%60,59, \%73,34) kazanıma rastlandığı tespit edilmiştir. Yenilenmiş Bloom taksonomisine göre 2017 fen taslak programlarının incelendiği çalışmada da (Cangüven, Öz, Binzet ve Avcı, 2017) bilişsel alan basamaklarının alt düzeyini ölçen kazanımların, üst düzeydekilere göre daha fazla olduğu ve tüm sınıf seviyelerinde anlama basamağındaki kazanımların fazlalık gösterdiği bulunmuştur. 2013 fen bilimleri öğretim programı kazanımlarını inceleyen bir başka çalışma sonuçları da benzerlik göstererek, bilişsel süreç boyutunda en fazla anlama, en az değerlendirme basamağında kazanım olduğunu tespit etmiştir (Zorluoğlu, Şahintürk ve Bağrıyanık, 2017).

Marzano taksonomisinin önemli özelliklerinden biri, psikomotor becerileri bilişsel alan içinde incelemesidir. Bir bilgi çeşidi olarak görülen bu alan, kazandırılması gereken bedensel veya el becerileri üzerine yoğunlaşır. Yapılan çalışma sonuçlarına bakıldığında, hiçbir disiplin alanında Marzano taksonomisindeki bilgi boyutu içindeki psikomotor alanına giren bir kazanım tespit edilmemiştir. Öğrencinin öğrenmesinde psikomotor boyutun bilişsel boyut ile birlikte kullanılması önemlidir (Ornstein ve Hunkins, 2014; Tuğrul, 2002). Ek olarak, incelenen kazanımlar, her disiplin alanında bilgi boyutunda daha çok bilgi ve zihinsel işlemler alanlarına dağılmıştır. Bilişsel boyutta ise, alma ve kavrama alanına giren kazanım sayısı fazladır. Biyoloji disiplininde 9, 10, ve 11. sınıflarda bilgiyi kullanma alanına giren kazanım gözlenmemiştir. Fizik disiplininde, her sınıf seviyesinde bilişsel boyutta analiz ve bilgiyi kullanma alanlarında az sayıda da olsa kazanım mevcuttur. Kimya disiplininde ise, 11. ve 12. sinıflarda en üst düzey olan bilgiyi 
kullanma alanına ait kazanım bulunmamıştır. Fen bilimleri öğretim programında 3 . ve 4 . sinıflarda, daha üst düzey olan analiz ve bilgiyi kullanma alanlarına ait kazanımlara rastlanmamıştır. Üst düzey becerileri (eşleştirme, hata analizi, karar verme, problem çözme vb.) içeren analiz ve bilgiyi kullanma alanlarına giren kazanımlar, incelenen tüm programlar içinde oldukça az yer almakta veya hiç bulunmamaktadır. Bu durum, Büyükalan ve Yıldırım (2019) tarafından Türkçe dersi öğretim programlarının Bloom taksonomisine göre incelendiği çalışma sonuçları ile benzerdir. İlave olarak bulunan bu sonuç, fen bilimleri dersi programının SOLO taksonomisine göre incelendiği araştırmada bulunan sonuçla uyumluluk göstermektedir (Dönmez ve Zorluoğlu, 2020). Oysaki üst düzey ve üst biliş ölçen kazanımlar, öğrenende güven oluşturarak kalıcı öğrenmenin temelini oluşturmaktadır (Bümen, 2006; Crowe, Dirks ve Wenderoth, 2008). Anlamlı öğrenme için üst düzey kazanımların yer alması ayrıca gerekmektedir (Eroğlu ve Kuzu, 2014; Mayer, 2002; MEB, 2018). Sınıf düzeyine paralel olarak kazanımların bilişsel düzeyinin arttırılması sağlanmalıdır (Anderson ve Krathwohl, 2010; Strimel, Scott, Kim ve Zhang, 2018). Tüm incelenen derslere ait öğretim programları göz önüne alındığında, kazanım düzeyinin homojen bir dağılım göstermediği bulunmuştur. Hâlbuki öğrenmenin etkisi açısından sınıf düzeylerine uygun kazanımların yazılması gerekmektedir (Anderson ve Krathwohl, 2001).

Yapılan çalışma bulgularının eğitmenler ve kitap yazarları tarafından incelenerek mevcut programların analiz edilmesi ve program geliştiricilere ileriki öğretim programı çalışmaları için fikir vermesi önerilmektedir. Programların farklı boyut ve açılardan sık sık değerlendirilmesi sağlanmalıdır. Değerlendirme süreçlerine bu programları uygulayıcıların da dahil edilmesi yoluna gidilebilir.

Birçok ülkede olduğu gibi ülkemizde de program geliştirme çalışmalarında önemli bir örnek olan ve altyapı oluşturan Bloom'un bilişsel alan taksonomisi ile ilgili çalışmaların sayısının fazla olduğu dikkat çekmektedir. Bu sınıflandırmalar dışında daha az tercih edilen Stahl ve Murphy (1981), Solo (Biggs ve Collis, 1982), Hauenstein (1998), Marzano (2001), Norman Webb (2002), Dettmer (2006) gibi taksonomilerin birçok farklı disiplinde kullanılması ve öğretim programlarını değerlendirmede test edilebilir olması sağlanabilir. Bu sayede geliştirilen taksonomilerin uygulanabilirliği araştırılmış ve daha ayrıntılı izlenerek kullanılabilirliği tartışılmış olur (Yüksel, 2007). Daha geniş ölçekte değerlendirme yapmak adına Marzano taksonomisine göre ülkemizdeki fen programlarının, farklı ülkelerin programları ile karşılaştırılması yapılabilir. Bu çalışma, Marzano taksonomisinin bilgi alanları ve bilişsel işlemler boyutları ile sınırlandırılmıştır. Taksonominin öz-sistem ve metabilişsel sistem boyutları dikkate alınarak araştırmaların boyutu genişletilebilir. Yine Marzano taksanomisi kullanılarak ders kitaplarının (Karadağ ve Kaya, 2017), etkinliklerin, ölçme değerlendirme boyutunda hazırlanan soruların değerlendirilmesinin yapılması verilecek öneriler arasındadır.

\section{Etik Kurul Onay Bilgileri}

$\mathrm{Bu}$ araştırmada kullanılan veriler doküman incelemesi yoluyla elde edilmiştir. $\mathrm{Bu}$ nedenle araştırma, etik kurul kararından muaftır.

Kaynaklar

Aer, A. (2006). Reflections on Bloom's revised taxonomy. Electronic Journal of Research in Educational Psychology, 4(1), 213-230.

Anderson, L. W., \& Krathwohl, D. R. (2001). Taxonomy for learning, teaching and assessing: A revision of Bloom's taxonomy of educational objectives. Needham Heights, MA: Allyn \& Bacon.

Anderson, L. W. ve Krathwohl, D. R. (2010). Öğrenme ögretim ve değerlendirme ile ilgili bir sinıflama [A taxonomy for learning, teaching, and assessing] (Çev. D. A. Özçelik). Ankara: Pegem A. 
Arı, A. (2013). Bilişsel alan sınıflamasında yenilenmiş Bloom, Solo, Fink, Dettmer taksonomileri ve uluslararası alanda tanınma durumları. Uş̧ak Üniversitesi Sosyal Bilimler Dergisi, 6(2), 259-290.

Asmi, S. O., Wonorahardjo, S., \& Widarti, H. R. (2019). The application of problem based learning assisted by blended learning in atomic spectroscopy material on cognitive learning outcomes and students' self system based on Marzano Taxonomy. European Journal of Open Education and E-learning Studies, 4(1), 88-99. doi: 10.5281/zenodo.3236775

Avşar, G. ve Mete, F. (2018). Türkçe öğretim programlarında kullanılan fiillerin yenilenmiş bloom taksonomisine göre sinıflandırılması. Karaelmas Journal of Educational Sciences, 6, 75-87.

Ayvacı, H. Ş. ve Şahin, Ç. (2009). Fen bilgisi öğretmenlerinin ders sürecinde ve yazılı sınavlarda sordukları soruların bilişsel seviyelerinin karşılaştırılması. Uludağ Üniversitesi Ĕgitim Fakültesi Dergisi, 22(2), 441-455.

Ayvacı, H. Ş., Alev, N. ve Yıldız, M. (2015). Öğrenme kazanımlarının tasarlanma sürecine ilişkin lisansüstü öğrencilerinin zihinsel modellerini belirlemeye yönelik bir çalışma. Kastamonu Ĕ̈itim Dergisi, 23(3), 1013-1030.

Ayyıldı,, Y., Aydın, A. ve Nakiboğlu, C. (2019). 2018 yılı ortaöğretim kimya dersi öğretim programı kazanımlarının original ve yenilenmiş Bloom taksonomisine göre incelenmesi. Mehmet Akif Ersoy Üniversitesi Eğitim Fakültesi Dergisi, 52, 340-376. doi: 10.21764 /maeuefd.540854

Biggs, J. B., \& Collis, K. (1982). Evaluating the quality of learning: The SOLO taxonomy. New York: Academic Press.

Bowen, G. A. (2009). Document analysis as a qualitative research method. Qualitative Research, 9, 27-40. doi: 10.3316/QRJ0902027

Bümen, N. T. (2006). A revision of the Bloom's taxonomy: A turning point in curriculum development. Ë̆itim ve Bilim, 31(142), 3-14.

Büyükalan, F. S., \& Baysal, S. B. (2019). Analysis of social studies curriculum objectives according to revised Bloom Taxonomy. Inonu University Journal of the Faculty of Education, 20(1), 234-253. doi: 10.17679/inuefd.435796

Büyükalan, F. S. ve Yıldırım N. (2019). Ortaokul Türkçe dersi öğretim programı kazanımlarının revize edilmiş bloom taksonomisine göre analizi. Elementary Education Online, 18(4), 1550-1573.

Cangüven, H. D., Öz, O., Binzet, G. ve Avcı, G. (2017). Milli Eğitim Bakanlığı 2017 fen bilimleri taslak programının yenilenmiş Bloom taksonomisine göre incelenmesi. International Journal of Eurasian Education and Culture, 2, 62-80.

Çelikkaya, (2019). 2018 Ortaöğretim kimya dersi öğretim programının kazanımlarının yeni Marzano taksonomisi ile değerlendirilmesi. (Yüksek lisans tezi). Yükseköğretim Kurulu Ulusal Tez Merkezi'nden edinilmiştir (Tez No: 600371).

Crowe, A., Dirks, C., \& Wenderoth, M. P. (2008). Biology in Bloom: Implementing Bloom's taxonomy to enhance student learning in biology. CBE Life Sciences Education, 7, 368381.

Demir, P. (2015). Yenilenmiş Bloom taksonomisine göre 2005 yll sosyal bilgiler ögretim programında yer alan kazanımlar ve seviye belirleme sinav sorularl. (Yüksek lisans tezi). Yükseköğretim Kurulu Ulusal Tez Merkezi'nden edinilmiştir (Tez No: 396923).

Demirel, Ö. (2000). Kuramdan uygulamaya eğitimde program geliştirme. Ankara: Pegem A.

Demir, E., Gacanoğlu, Ş. ve Nakiboğlu, C. (2017). 2013 kimya dersi öğretim programına yönelik öğretmen görüşleri doğrultusunda 2017 kimya dersi öğretim programının değerlendirilmesi. Journal of the Turkish Chemical Society Dergisi, 2(2), 135-184.

Dettmer, P. (2006). New Blooms in established fields: Four domains of learning and doing. Roeper Review, 28(2), 70-78.

Deveci, İ. (2018). Türkiye'de 2013 ve 2018 y1lı fen bilimleri dersi öğretim programlarının temel öğeler açısından karşılaştırılması. Mersin Üniversitesi Eğitim Fakültesi Dergisi, 14(2), 799-825. doi: 10.17860/mersinefd. 342260 
Doğan, Y. ve Burak, D. (2018). 4. sınıf fen bilimleri dersi kazanımlarının revize edilmiş Bloom taksonomisine göre incelenmesi. Akdeniz Ĕ̈itim Araştırmaları Dergisi, 12(23), 34-56. doi: 10.29329/mjer.2018.138.3

Dönmez, H. ve Zorluoğlu, S. L. (2020). Fen bilimleri dersi öğretim programı 6., 7. ve 8. sinıf kazanımlarının SOLO taksonomisine göre incelenmesi. Celal Bayar Üniversitesi Sosyal Bilimler Dergisi, 18(1), 85-95. doi: 10.18026/cbayarsos.547938

Dubas, J. M. ve Toledo, S. A. (2016). Taking higher order thinking seriously: Using Marzano's taxonomy in the economics classroom. International Review of Economics Education, 21, 12-20. doi: 10.1016/j.iree.2015.10.005

Eke, C. (2015). Dalgalar ünitesindeki kazanımların yenilenmiş Bloom taksonomisine göre incelenmesi. Ĕ̈itim ve Öğretim Çalı̧̧maları Dergisi, 4(2), 346-353.

Eroğlu, D. ve Kuzu, T. S. (2014). Türkçe ders kitaplarındaki dilbilgisi kazanımlarının ve yenilenmiş Bloom taksonomisine göre değerlendirilmesi. Başkent University Journal of Education, 1(1), 72-80.

Fleiss, J. L. (1971). Measuring nominal scale agreement among many raters. Psychological Bulletin, 7, 378-382.

Gökler, Z. S., Aypay, A. ve Arı, A. (2012). İlköğretim ingilizce dersi hedefleri kazanımları SBS soruları ve yazılı sınav sorularının yeni Bloom taksonomisine göre değerlendirilmesi. Eğitimde Politika Analizi Dergisi, 1(2), 114-133.

Hauenstein, A. D. (1998). A conceptual framework for educational objectives. Lanham, Maryland: University Press of America, Inc.

Insani, M. D., Pratiwi, N., \& Muhardjito, M. (2019). Higher-order thinking skills based on Marzano taxonomy in basic biology I course. JPBI (Jurnal Pendidikan Biologi Indonesia), 5(3), 521-528. doi: https://doi.org/10.22219/jpbi.v5i3.10171

Irvine, J. (2017). A comparison of revised Bloom and Marzano's new taxonomy of learning. Research in Higher Education Journal, 3, 1-16.

Karagöl, E. (2020). Current Turkish education programs according to renewed Bloom taxonomy. Journal of Language Education and Research, 6(1), 56-71. doi: 10.31464/jlere.666641

Karadağ, R. ve Kaya, Ş. (2017). Marzano taksonomisine göre ilkokul programlarındaki kazanımların değerlendirilmesi: Bir durum çalışması. Kuramsal Eğitimbilim Dergisi, 10(2), 220-250. doi: 10.5578/keg.33169

Karip, F. (2019). İlkokul görsel sanatlar dersi kazanımlarının yenilenmiş Bloom taksonomisine göre değerlendirilmesi. Uluslararası Türkçe Edebiyat Kültür Eğitim Dergisi, 8(3), 19291948.

Kirk, J., \& Miller, M. L. (1986). Reliability and validity in qualitative research. Beverly Hills: Sage Publications.

Koca, S. A. ve Şen, A. İ. (2006). Orta öğretim öğrencilerinin matematik ve fen derslerine yönelik olumsuz tutumlarının nedenleri. Eurasian Journal of Educational Research, 23, 137-147.

Marzano, R. J. (2001). Designing a new taxonomy of educational objectives. California: Corwin Press.

Marzano, R. J., \& Kendall, J. S. (2007). The new taxonomy of educational objectives (2nd ed.). Thousand Oaks, CA: Corwin Press.

Marzano, R. J., Pickering, D. J., Arredondo, D. E., Blackburn, G. J., Brandt, R. S., Moffett, C. A., Paynter, D. E., Pollock, J. E., \& Whisler, J. S. (1997). Dimensions of learning teacher's manual $\left(2^{\text {nd }} \mathrm{ed}.\right)$. Aurora, CO: McREL.

Mayer, R. E. (2002). Rote versus meaningful learning. Theory Into Practice, 41(4), 226-232.

MEB (2018). 2023 Eğitim Vizyonu. Milli Eğitim Bakanlı̆̆ , Ankara.

Nakyam, J., Kwangsawad, T., \& Sriampai, P. (2013). The development of foreign language substance group curriculum based on Marzano's taxonomy. Educational Research and Reviews, 8(14), 1109-1116. doi: 10.5897/ERR2012.195

Ornstein, A. C. ve Hunkins, F. P. (2014). Eğitim programı: temeller, ilkeler ve sorunlar (Çev. Komisyon). Ankara: Eğitim Yayınevi. 
Rasyidi, D. A. ve Winarso, W. (2020). The proportion of cognitive aspects of question in mathematics textbook based on Marzano's taxonomy: An Indonesian case in implementing new curriculum. EduMa: Mathematics Education Learning and Teaching, 9(2), 79-89.

Webb, N. L. (2002). Alignment study in language arts, mathematics, science, and social studies of state standards and assessments for four states. Washington, DC: Council of Chief State School Officers.

O'leary, Z. (2004). The essential guide to doing research. London: Sage Publications Ltd.

Özdemir, M.S., Altıok, S. ve Baki, N. (2015). Bloom'un yenilenmiş taksonomisine göre sosyal bilgiler öğretim programı kazanımlarının incelenmesi. Ĕgitim ve Öğretim Araştırmaları Dergisi, 4(3), 363-375.

Sönmez, V. (2015). Program geliştirmede öğretmen el kitabı. Ankara: Anı Yayınc1lık.

Stahl, R. J., \& Murphy, G. T. (1981). The domain of cognition: An alternative Bloom's cognitive domain within the framework af an information processing model. ERIC Documents Reproduction Service No: ED 208511.

Strimel, G. J., Bartholomew, S., R. B., Kim, E., \& Zhang, L. (2018). An investigation of engineering design cognition and achievement in primary school. Journal for STEM education research, $1(1-2), 173-201$.

Tanık, N. ve Saraçoğlu, S. (2011). Fen ve teknoloji dersi yazılı sorularının yenilenmiş Bloom taksonomisine göre incelenmesi. TÜBAV Bilim Dergisi, 4(4), 235-246.

Timofte, R. S., \& Siminiciuc, L. (2018). Utilisation of rasch model for the analysis of an instrument developed by mapping items to cognitive levels of Marzano taxonomy. Acta Didactica Napocensia, 11(2), 71-78.

Toledo, S., \& Dubas, J. M. (2016). Encouraging higher-order thinking in general chemistry by scaffolding student learning using Marzano's taxonomy. Journal of Chemical Education, 93, 64-69.

Tuğrul, B. (2002). Bloom'un taksonomik süreçlerine etkileşimci taksonomi açısından bir bakış. Hacettepe Üniversitesi Ĕgitim Fakültesi Dergisi, 23,267-274.

Viji, V., \& Benedict, K. Y.(2017). Conceptualization, theory and practice of Marzano's taxonomy in science teaching: An objective portrayal by the investigator. International Journal of Research Culture Society, 1(8), 193-200.

Yıldırım, A. ve Şimşek, H. (2016). Sosyal bilimlerde nitel araştırma yöntemleri. Ankara: Seçkin Yayinevi.

Yüksel, S. (2007). Bilişsel alanın sınıflamasında (taksonomi) yeni gelişmeler ve sınıflamalar. Türk Ĕ̈itim Bilimleri Dergisi, 5(3), 479-509.

Yüksel Ayten, M. ve Hayırsever, F. (2019). Ortaöğretim programlarının öğrenci görüşlerine göre değerlendirilmesi. Mersin Üniversitesi Eğitim Fakültesi Dergisi, 15(2), 290-323. doi: 10.17860/mersinefd.569193

Zorluoğlu, L. S., Güven, Ç. ve Korkmaz, Z. S. (2017). Yenilenmiş Bloom taksonomisine göre analiz örneği: 2017 taslak ortaöğretim kimya dersi öğretim programı. Mediterranean Journal of Humanities, 7(2), 467-479.

Zorluoğlu, L. S., Olgun, M. ve Kızılaslan, A. (2020). Content analysis of researches on the revised Bloom taxonomy related to the science in Turkey. Trakya Eğitim Dergisi, 10(1), 23-32.

Zorluoğlu, L. S., Şahintürk, A. ve Bağrıyanık, E. K. (2017). 2013 yılı fen bilimleri öğretim programı kazanımlarının yenilenmiş Bloom taksonomisine göre analizi ve değerlendirilmesi. Bartın Üniversitesi Ĕ̈itim Fakültesi Dergisi, 6(1), 1-15.

\section{Introduction}

\section{Extended Abstract}

The quality of teaching is guided by a rich and deep curriculum, one of the most important aspects of education. Cognitive classifications, namely taxonomies, are used to evaluate educational objectives as the road maps of these programs. Taxonomies help understand the educational objectives, which are created to achieve goals of the curricula in educational systems. As one of these taxonomies, Marzano' new taxonomy, is discussed in the scope of the current study. The 
new taxonomy of Marzano includes two main domains. The first of these domains is related to the domains of knowledge and it covers three basic areas. These areas are information, mental and psychomotor procedures. The other domain is cognitive system includes processes that cover retrieval, comprehension, analysis, and knowledge utilization. The purpose of the study is to examine the educational objectives of 2018 biology, physics, chemistry and science curriculum programs according to the new taxonomy of Marzano. Based on this purpose, the research questions of the study are as follows:

1. How is the distribution of secondary biology curriculum objectives in the dimensions of knowledge and cognitive processes in Marzano's new taxonomy?

2. How is the distribution of secondary physics curriculum objectives in the dimensions of knowledge and cognitive processes in Marzano's new taxonomy?

3. How is the distribution of secondary chemistry curriculum objectives in the dimensions of knowledge and cognitive processes in Marzano's new taxonomy?

4. How is the distribution of science curriculum (Primary and Middle (3th, 4th 5th, 6th, 7 th, and 8th) schools objectives in the dimensions of knowledge and cognitive processes

\section{Method} in Marzano's new taxonomy?

Document analysis, one of the qualitative research methods, was conducted in the study. Secondary school biology, physics, chemistry and science (3rd, 4th, 5th, 6th, 7th, and 8th grades) curricula, which were published in 2017 and then updated and implemented in 2018, were investigated for the study. Descriptive content analysis of 731 educational objectives was performed with respect to the domains of knowledge and cognitive system of the Marzano's new taxonomy. The educational objectives of the curriculum for each discipline were examined in detail on the basis of grade levels and units. Data were tabulated by calculating frequency and percentage values. The latest findings were shared with two education experts and their opinions were obtained to make an agreement on the coding process. The working group consists of researchers specialized in chemistry, science and physics disciplines. Inter-rater reliability value (kappa value of Fleiss) was calculated among the three researchers who coded the educational objectives and 0.79 was found.

\section{Result and Discussion}

In the secondary school biology discipline, 91 educational objectives were analyzed within a total of 12 units. In the 9th and 11th grade levels, educational objectives were located in the information area as one of the knowledge domains at most $(90.90 \%, 67,64 \%)$. In addition, it was found that the number of educational objectives entered into mental procedures is higher at the 10thand 12th grades $(58.82 \%, 72,41 \%)$. In the cognitive system domain, the highest level was seen in retrieval and comprehension level at the 9th grade $(45.45 \%)$, whereas educational objectives was found most in the comprehension level at the 10,11 , and 12 th grades $(41.17 \%, 73.52 \%, 58.62 \%)$. In the secondary education physics course, total 213 educational objectives in 18 units were examined. It was determined that the most mental procedures were in the 9th, 10th, 11th, and 12th grade educational objectives $(68,19 \%, 64.11 \%, 79.03 \%, 72.06 \%)$. In the cognitive system domain, the highest level was seen in comprehension level at the 9th, 10th, and 12th grades $(54.55 \%, 53,84 \%$, $60.29 \%$ ). Educational objectives in the 11th grade level were identified most in retrieval level $(45.16 \%)$. In the secondary chemistry course, a total of 127 educational objectives were taken into account in 19 units. The number of educational objectives was determined most in the mental procedure at the 9 th, 10 th, 11 th, and 12 th grades $(71.05 \%, 86.96 \%, 91.44 \%, 87.09 \%)$. The highest level was observed in comprehension level as one of cognitive procedures at the 9th, 10th, 11th, and 12 th grades $(44.73 \%, 56.53 \%, 88.57 \%, 51.61 \%)$. In the science curriculum (3rd, 4th, 5th, 6th, 7 th, and 8th grades) a total of 300 educational objectives in 42 units were evaluated. The highest level was found in information at the $3 \mathrm{rd}$ and 4 th grade objectives $(74.99 \%, 65.12 \%)$. On the other hand, there were more educational objectives classified in mental procedures at the 5 th, 6 th, 7 th, and 8 th grades $(52,78 \%, 67.74 \%, 68,17 \%, 58.33 \%)$. In the cognitive system dimension, there have been more educational objectives found in comprehensionlevel in all grades $(52.78 \%$, $65.12 \%, 55.56 \%, 67.75 \%, 60.59 \%, 73.34 \%)$. 